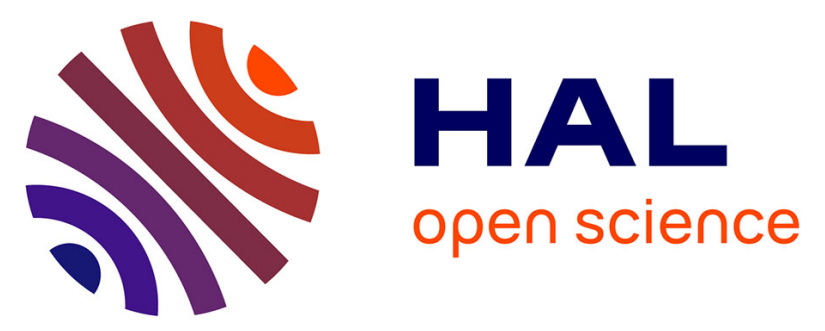

\title{
Intracellular location matters: rationalization of the anti-inflammatory activity of a manganese( ii ) superoxide dismutase mimic complex
}

\author{
Emilie Mathieu, Anne-Sophie Bernard, Elodie Quévrain, Martha
}

Zoumpoulaki, Sébastien Iriart, Caroline Lung-Soong, Barry Lai, Kadda

Medjoubi, Lucas Henry, Sounderya Nagarajan, et al.

\section{To cite this version:}

Emilie Mathieu, Anne-Sophie Bernard, Elodie Quévrain, Martha Zoumpoulaki, Sébastien Iriart, et al. Intracellular location matters: rationalization of the anti-inflammatory activity of a manganese( ii ) superoxide dismutase mimic complex. Chemical Communications, 2020, 56 (57), pp.7885-7888. 10.1039/d0cc03398g . hal-03180781

\section{HAL Id: hal-03180781 \\ https://hal.sorbonne-universite.fr/hal-03180781}

Submitted on 25 Mar 2021

HAL is a multi-disciplinary open access archive for the deposit and dissemination of scientific research documents, whether they are published or not. The documents may come from teaching and research institutions in France or abroad, or from public or private research centers.
L'archive ouverte pluridisciplinaire HAL, est destinée au dépôt et à la diffusion de documents scientifiques de niveau recherche, publiés ou non, émanant des établissements d'enseignement et de recherche français ou étrangers, des laboratoires publics ou privés. 


\section{Intracellular location matters: rationalization of the anti-inflammatory activity of a manganese(II) superoxide dismutase mimic complex $\dagger$}

Emilie Mathieu, ${ }^{\mathrm{a}}$ Anne-Sophie Bernard, ${ }^{\mathrm{a}}$ Elodie Quevrain, ${ }^{\mathrm{a}}$ Martha Zoumpoulaki, ${ }^{\mathrm{a}}$ Sebastien Iriart, ${ }^{\mathrm{a}}$ Caroline Lung-Soong, Barry Lai, ${ }^{\mathrm{b}}$ Kadda Medjoubi, ${ }^{\mathrm{c}}$ Lucas Henry, ${ }^{\mathrm{a}}$ Sounderya Nagarajan, ${ }^{\text {de }}$ Florent Poyer, ${ }^{\text {de }}$ Andreas Scheitler,Ivana Ivanovi ${ }^{-}$ Burmazovic',(f) Sergio Marco,(de)Andrea Somogyi, Philippe Seksik,g Nicolas Delsuca and Clotilde Policar ${ }^{f}$

A conjugate of a Mn-based superoxide dismutase mimic with a Re-based multimodal probe 1 was studied in a cellular model of oxidative stress. Its speciation was investigated using $\mathrm{Re}$ and $\mathrm{Mn}$ $X$-fluorescence. Interestingly, $\underline{1}$ shows a distribution different from its unconjugated analogue but a similar concentration in mitochondria and a similar bioactivity.

A new class of metallo-drugs with catalytic activity and inspired from metalloenzymes is emerging: they are of interest as they may allow decreasing the administered doses thus reducing potential side effects, toxicity and treatment costs. ${ }^{1}$ Superoxide dismutase mimics, SOD mimics, ${ }^{2-10}$ belong to this family of catalytic drugs. They reproduce the catalytic activity of superoxide dismutases, metalloproteins involving $\mathrm{Cu}-\mathrm{Zn}, \mathrm{Mn}, \mathrm{Fe}, \mathrm{Ni}$ or $\mathrm{Cu}$ at the active site that protect the cell against oxidative stress by catalysis of superoxide dismutation. ${ }^{11,12}$

Their use in a biological context raises new challenges. Indeed, parameters other than intrinsic catalytic activity are essential for good efficacy: cell penetration, speciation, and intracellular location(s) and concentration(s) ${ }^{13}$ It is therefore important to investigate the activity of SOD mimics directly in the cellular environment under oxidative stress, which is defined as an imbalance between the production of reactive oxygen species

\footnotetext{
${ }^{a}$ Laboratoire des biomolécules, LBM, Département de chimie, Ecole normale supérieure, PSL University, Sorbonne université, CNRS, 75005 Paris, France. E-mail: clotilde.policar@ens.fr

${ }^{b}$ X-ray Science Division, Argonne National Laboratory, Argonne, Illinois 60439, USA

${ }^{c}$ Synchrotron SOLEIL, BP 48, Saint-Aubin, 91192 Gif sur Yvette, France

${ }^{d}$ Institut Curie, Research Center, PSL University, Chemistry, Modelling and Imaging for Biology (CMIB), Bât 110-112, Centre Universitaire, F-910405 Orsay, France e INSERM U 1196, CNRS UMR 9187, Paris-Saclay University, Paris-Sud University, University Centre, Orsay, France

${ }^{f}$ Department of Chemistry and Pharmacy, University of Erlangen-Nürnberg, Egerlandstr. 1, 91058 Erlangen, Germany

${ }^{g}$ Sorbonne Université, Ecole normale supérieure, PSL University, CNRS, INSERM, AP-HP, Laboratoire des biomolécules, LBM, 75012 Paris, France
}

(ROS) and endogenous antioxidants. ${ }^{14}$ Some pathologies, such as inflammatory bowel diseases (IBD) or amyotrophic lateral sclerosis (ALS), have been associated with impairment of SOD, either because the enzyme is under-expressed or expressed in an inactive form. ${ }^{15,16}$ SOD mimics are able to substitute for SODs in SOD-deficient organisms, protect against radiation and ischemia-reperfusion injuries, and limit inflammation and other pathological processes associated with oxidative stress. ${ }^{3-5,8,17}$ Most of the metal complexes studied in the literature for their bioactivity are used as anticancer or antibacterial agents, and thus most bioanalyses focus on their toxicity towards cancer cells or micro-organisms. In contrast, SOD-mimics are meant to restore normal functioning of cells by limiting oxidative stress. As such, specific non-routine strategies are required to evaluate their bioactivity. ${ }^{2,18,19}$ We have recently set up several cellular models of oxidative stress, ${ }^{2,18-20}$ one of which consists of epithelial cells in which inflammation can be induced, ${ }^{21}$ which can be used to probe the bioactivity of SOD mimics. ${ }^{18} \mathrm{~A}$ key question for rationalizing the bioactivity of a molecule is its intracellular concentration. The actual quantity in cells, and not the concentration of incubation, is an important consideration for rationalizing the activity. ${ }^{18}$ In addition, cells are compartmented, so bioactivity depends on the sub-cellular distribution. In the case of protection against oxidative stress, mitochondria are believed to be a fragile site that requires specific protection. ${ }^{22,23}$

In the present work, we have designed a new Mn-SOD mimic 1 (Fig. 1) that was obtained by conjugation of a Re-tris carbonyl probe that can be used for several imaging modalities, ${ }^{24-27}$

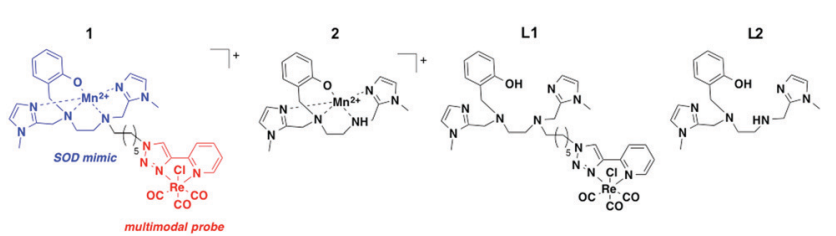

Fig. 1 Structures of $\underline{\mathbf{1}}, \underline{\mathbf{2}}, \underline{\mathbf{L}} \underline{\mathrm{I}}$, and $\underline{\mathbf{L}} \mathbf{2}$. 
including X-ray fluorescence, ${ }^{25}$ to the parent Mn-SOD mimic 2 . This enabled us to image $\mathrm{Mn}$ and Re directly, in order to correlate the distribution of $\mathrm{Mn}$ with that of the Re-tagged ligand, providing an insight into the stability of the SOD mimic in cells. We have studied the bioavailability and intracellular distribution of $\underline{\mathbf{1}}$. Its activity in cells was determined and compared with the non-conjugated parent complex 2. Surprisingly, the new conjugate $\mathbf{1}$ showed a markedly different intracellular distribution and accumulation, while displaying overall similar bioactivity to the unconjugated analogue $\underline{2}$. Interestingly, the concentrations of $\underline{1}$ and $\underline{\mathbf{2}}$ are similar at the mitochondria, which is recognized to be a fragile organelle to be protected under oxidative stress.

This study is in line with other studies meant to better understand the bioactivity of SOD mimics, including studies on mechanisms of SOD mimics, ${ }^{28-30}$ on the application of SOD mimics, ${ }^{4,7,10,31,32}$ or on the distribution and speciation of these compounds. ${ }^{13,18,33,34}$

The multimodal probe was synthesized with a pendant aldehyde moiety meant for conjugation with the ligand $\mathbf{L} 2$ via a reductive amination coupling (ESI, $\dagger$ Section 5 ). The effect of functionalization on the lipophilicity of the $\underline{\mathbf{L}} \mathbf{2}$ ligand was studied using analytical HPLC (ESI, $\dagger$ Section 6), showing that coupling with the probe increased the retention time of $\underline{\mathbf{L}} \mathbf{1}$ compared to $\mathbf{L} \mathbf{2}$ on the reversed-phase $\mathrm{C} 18$ column, and thus the lipophilicity of the molecule (Fig. S5, ESI $\dagger$ ). ${ }^{35}$ The conjugation neither modified the fluorescence nor the IR properties of the probe (Fig. S1 and S2, ESI $\dagger$ ). L1 was purified by HPLC and titrated by UV-visible spectrophotometry (ESI, $\uparrow$ Sections 6 and 7). Metalation with $\mathrm{MnCl}_{2}$ leads to the formation of $\underline{\mathbf{1}}$ (ESI, $\dagger$ for characterization Section 7).

Cyclic voltammetry experiments at different scan rates were performed in HEPES buffer (0.1 M, pH 7.5) (Fig. S3, ESI $\dagger$ ). A quasi-reversible system was obtained with $\Delta E_{\mathrm{p}}=90 \mathrm{mV}$ at $50 \mathrm{mV} \mathrm{s}^{-1}$. The apparent standard potential of $\underline{1}$ is $243 \mathrm{mV} v s$. SCE (saturated calomel electrode), slightly higher than for 2 (196 mV vs. SCE). ${ }^{36}$ A similar difference in potential has been previously described for similar functionalization of $\mathbf{L 1},{ }^{37}$ and other complexes containing amine based-ligands, ${ }^{38,39}$ associated with the weaker basicity of a tertiary amine. Importantly, this value remains in the range appropriate for superoxide dismutation. ${ }^{2}$ The dissociation constants $\left(K_{\mathrm{d}}\right)$ were determined spectrophotometrically to be $9 \pm 4 \times 10^{-8}$ and $7 \pm 3 \times 10^{-7}$ at pH 7.5 for 1 and 2 respectively (see Fig. S4 and ESI, $\dagger$ Section 7), which is similar to previous measurements for $2 .^{18,37,40}$ These association constants mean that under the incubation conditions $(100 \mu \mathrm{M}), 97 \%$ of $\mathbf{L 1}$ and $\mathbf{9 2 \%}$ of $\mathbf{L} 2$ are coordinated.

The intrinsic SOD activity, or activity outside of any cellular context, was determined by the McCord-Fridovich assay (Table $\mathrm{S} 1, \mathrm{ESI} \dagger)$ and provided as a $k_{\mathrm{McCF}}(\mathrm{ESI}, \dagger$ Section 3$)$. The $k_{\mathrm{McCF}}$ of 1 is $6.4 \times 10^{6} \mathrm{M}^{-1} \mathrm{~s}^{-1}$, similar to the constant previously reported for $\underline{2}\left(7.0 \times 10^{6} \mathrm{M}^{-1} \mathrm{~s}^{-1}\right) \cdot{ }^{36}$ The SOD-like activity of $\underline{1}$ was also investigated with a high excess of superoxide using a direct stopped-flow measurement combined with fast diode-array UV-vis detection. ${ }^{30,37,41}$ The $k_{\text {cat }}$ value of $6.46 \times 10^{6} \mathrm{M}^{-1} \mathrm{~s}^{-1}$ in MOPS buffer (60 mM, ionic strength $150 \mathrm{mM}, \mathrm{pH} 7.8$ ) is consistent with the $k_{\mathrm{McCF}}$, confirming that coupling with the probe does not change the intrinsic SOD activity of the SOD mimic.

The bioactivity was investigated in a cellular model of oxidative stress. Briefly, in this model, human intestinal epithelial cells HT29-MD2 are activated with bacterial lipopolysaccharide (LPS), a component of the bacterial cell-membrane, to generate an inflammatory reaction associated with oxidative stress in cells. ${ }^{18,21}$ Prior to the study of the cellular bioactivity of the complex, we characterized the bioavailability of the complexes in HT29-MD2, by studying the accumulation and subcellular location of $\underline{\mathbf{1}}$. The quantification of the total manganese content was determined by electron paramagnetic resonance (EPR) titration in HT29-MD2 cells after a 6-hour incubation with $\underline{1}$ and acid treatment to release $\mathrm{Mn}$ from all coordination sites. ${ }^{18}$ We also compared the Mn-content in a fraction enriched in mitochondria using inductively coupled plasma mass spectrometry (ICP-MS), which provides a higher sensitivity than EPR (ESI, $\dagger$ Section 8). The quantification indicates that intracellular overall accumulation is higher for $\underline{1}$ than for $\underline{2}$, (Fig. 2A.a., C vs. B) whereas the Mn-content in the mitochondrial fraction was not significantly different for cells incubated with $\underline{1}$ or $\underline{2}$ (Fig. 2A.b., C vs. B).

Cells incubated with $\underline{1}$ were studied by IR and X-ray fluorescence microspectroscopies. To avoid possible re-localization upon chemical fixation and drying, we have used a cryofixationlyophilisation procedure, as previously described. ${ }^{18}$ Fourier transform infrared spectromicroscopy (FTIR-SM) showed the two IR-bands (A1 and E) of the Re-tris-carbonyl core in cryofixed and freeze-dried HT29-MD2 cells incubated with 1 (ESI, $\dagger$ Sections 8 and Fig. S9).

The intracellular distribution of $\underline{\mathbf{1}}$ was further studied by SR$\mathrm{XRF}$. Using this technique, heavy elements can be mapped in a single cell with good spatial resolution $(c a .300 \mathrm{~nm}) .{ }^{42,43}$ Fig. 3 shows the distribution of phosphorus (P), manganese (Mn), zinc ( $\mathrm{Zn})$ and
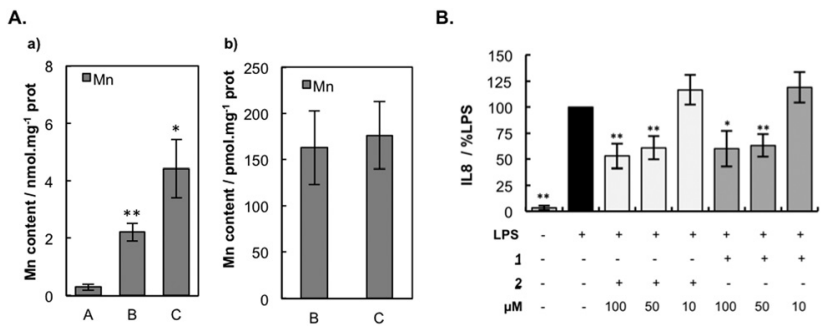

Fig. 2 (A) Quantification of total $M n$ content in cell lysates (a), or mitochondria-enriched fractions (b). HT29-MD2 cells were incubated for 6 hours under different conditions: (A) medium only; (B) 2 (100 $\mu \mathrm{M})$; (C) $1(100 \mu \mathrm{M}, 0.02 \% \mathrm{DMSO})$. (a) Total $\mathrm{Mn}$ content was determined in acid-digested cell lysates by titration using EPR (ESI†). Data represent mean \pm SEM for 4 independent experiments. $\left.{ }^{*}\right) p<0.05$, $\left.{ }^{* *}\right) p<0.01$ vs. (A). (b) Total Mn content was determined in mitochondria-enriched fractions by ICP-MS. Mitochondria were isolated using a mitochondria isolation kit (Thermo Fisher Scientific). Data represent mean \pm SEM for 7 independent experiments. (B) IL8 secretion in HT29-MD2 cells. Intestinal epithelial cells HT29-MD2 were incubated for 7 hours under different conditions indicated in the figure. LPS $\left(0.1 \mu \mathrm{g} \mathrm{mL}^{-1}\right)$ was added at the end of the first hour. Data represent means \pm SEM for 7-10 independent experiments. $\left.\left(^{*}\right) p<0.05,{ }^{* *}\right) p<0.01$ vs. B. 

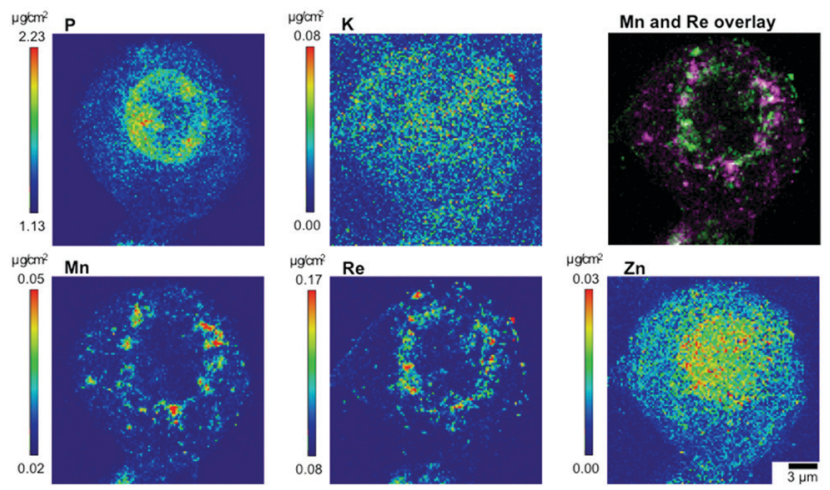

Fig. 3 Elemental distribution of $P, K, M n, R e$, and $Z n$ in an HT29-MD2 cell incubated with 1 . The phosphorus (P), and zinc ( $\mathrm{Zn}, \mathrm{K}$-lines) maps are used to identify the nucleus area. The overlay (top right) corresponds to the $\mathrm{Mn}$ (magenta) and Re (L-lines) (green) maps. The regions corresponding to an overlap of both elements are displayed in white. Intestinal epithelial cells HT29-MD2 were incubated for 2 hours with 1 (100 $\mu \mathrm{M}, 0.02 \% \mathrm{DMSO})$ before cryofixation and freeze-drying. Images were recorded on the 2-ID-D beamline of the APS synchrotron (excitation at $12.0 \mathrm{keV}$; integration time, $2 \mathrm{~s}$ per pixel; pixel size, $200 \mathrm{~nm}$ ). Scale bar, $3 \mu \mathrm{m}$.

rhenium (Re) in a single cryofixed HT29-MD2 cell. The mapping of $\mathrm{P}$ and $\mathrm{Zn}$ (K-lines) reveals the nucleus location. ${ }^{44}$ Since $\mathrm{Re}$ is an ultratrace element in biological samples, ${ }^{45}$ the Re signal observed (L-lines, see the ESI $\dagger$ ) can be assigned to the presence of the ligand $\underline{\mathbf{L}} \mathbf{1}$ or of the complex. Note that the Mn map corresponds to that of $\underline{1}$ and endogenous Mn, the latter being less abundant (see Fig. 2A). As can be seen from the overlay of the Mn and Re maps, part of the Mn map overlaps with that of Re, suggesting that in these areas (white Fig. 2B, Fig. S14 and S15, ESI $\dagger$ ) complex 1 can still be intact. Moreover, it shows that 1 is not homogeneously distributed, but has a perinuclear distribution with a punctate appearance. This is a striking difference from the homogenous distribution of $\underline{2}$ in cells and from the distribution of $\mathrm{Mn}$ in cells incubated with $\mathrm{MnCl}_{2}{ }^{18} \mathrm{In}$ addition, cells were co-incubated with a mitochondrial marker, Mitotracker $^{\mathrm{TM}}$ deep red, before cryofixation and freeze-drying, and fluorescence images of stained cells were recorded before $\mathrm{X}$-fluorescence analysis (Fig. S12 and S13, ESI $\dagger$ ). Overlay of the Mitotracker signal with the Re map (Fig. S13, ESI $\dagger$ ) showed areas where the two signals overlap. This revealed that $\underline{1}$ is localized in perinuclear organelles including mitochondria, but not exclusively: 1 was clearly also localized in organelles other than mitochondria. The more hydrophobic nature of $\underline{\mathbf{L}} \mathbf{1}$ could explain the accumulation of $\underline{1}$ in membrane-rich organelles.

Finally, X-fluorescence spectroscopy can provide quantitative information on the amount of heavy elements in cells. Using the appropriate standards, we were able to determine the amount of $\mathrm{Mn}$ and other elements (P, S, K, Fe) in cells (Fig. S11, $\mathrm{ESI} \dagger)$. The average concentration of $\mathrm{Mn}$ for cells incubated with

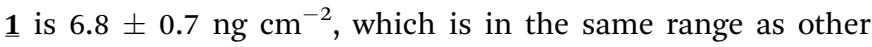

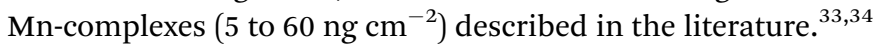

The anti-inflammatory activity of 1 was investigated in HT29MD2 activated by LPS, used as a cellular model of oxidative stress. ${ }^{18}$ Two markers of inflammation, interleukin 8 (IL8) secretion (Fig. 2B, and Fig. S7, ESI $\dagger$ ) and cyclooxygenase 2 (COX2) expression (Fig. S8, ESI $\dagger$ ), were evaluated. These two markers are overexpressed in
LPS-activated HT29-MD2 cells, which is consistent with the generation of an inflammatory reaction. ${ }^{18} \underline{1}$ and $\underline{2}$ were assayed at 100,50 , and $10 \mu \mathrm{M}$ incubation concentrations at which no toxicity was observed, with or without LPS (Fig. S6, ESI $\dagger$ ). Interestingly, both compounds exert a similar anti-inflammatory activity in LPS-activated cells at 100 and $50 \mu \mathrm{M}$ as can be seen from the decrease in IL8 secretion (Fig. 2B) and COX2 expression (Fig. S8, ESI $\dagger$ ) compared to LPS-activated cells. No effect of the compounds was observed at $10 \mu \mathrm{M}$. They both had a weak pro-inflammatory effect when used on non-activated cells at 100 or $50 \mu \mathrm{M}$ (Fig. S7, ESI $\dagger$ ). The $\mathrm{Zn}^{2+}$-complexes were used as redox inactive analogues of $\underline{\mathbf{2}}^{18}$ and $\underline{1}$ and displayed no effect on IL8 production on LPS-activated, or non-activated cells (Fig. S7, ESI $\dagger$ ). Note that DMSO, which is used to solubilize $\underline{1}$ and was present in the cell culture medium at a final concentration of $0.02 \%(\mathrm{v} / \mathrm{v})$, showed no effect on IL8 production (Fig. S7, ESI $\dagger$ ). Finally, $\mathrm{MnCl}_{2}$ also does not exhibit any anti-inflammatory activity (Fig. S7, ESI $\dagger$ ) Altogether these data demonstrate that $\underline{1}$ has an anti-inflammatory activity similar to $\underline{2}$ in LPS-activated cells. This anti-inflammatory activity is associated with their redox properties, as the zinc-analogues have shown no effect (Fig. S7, ESI $\dagger$ ).

The mitochondrial manganese SOD (MnSOD) is overexpressed in cells activated with LPS (Fig. S8, ESI $\dagger$ ) as a feedback response of the cell against oxidative stress. ${ }^{18,46-48} \underline{1}$ efficiently decreases MnSOD overexpression at 100 and $50 \mu \mathrm{M}$ in LPS activated cells, with no detectable effect at $10 \mu \mathrm{M}$, which correlates well with the IL8 and COX2 data (Fig. S7 and S8, ESI $\dagger$ ). Its ability to limit MnSOD overexpression in LPS-activated cells can be interpreted as an efficient anti-superoxide effect. ${ }^{18}$ Interestingly, like $\underline{\mathbf{2}}, \underline{\mathbf{1}}$ is able to complement SOD and to protect mitochondria from oxidative damage. The conjugation to the Re-tris carbonyl probe did not change the overall biological activity of the complex, although it changed drastically its location.

Anti-inflammatory and antioxidant effects of $\underline{\mathbf{2}}$ and $\underline{\mathbf{1}}$ are in a similar range, as demonstrated by IL8, COX2, and MnSOD expression levels: both complexes are efficient in cells and can reach their target(s). In addition, $\underline{\mathbf{2}}$ and $\underline{\mathbf{1}}$ are able to complement the mitochondrial MnSOD under stress conditions. Surprisingly, 1 and $\underline{2}$ have a similar bioactivity, while showing a different overall concentration and a markedly different cellular distribution, but a similar mitochondrial Mn-content. Finally, this similar mitochondrial Mn-content bioactivity associated with a similar bio-activity makes sense as mitochondria are believed to require specific protection under oxidative stress. ${ }^{22,23}$ This stresses the fact that bioactivities are compartmentalized: "more in cells" does not track with "better bioactivity". We propose that context-dependent bioactivity is a key factor for the efficacy of these new classes of metallodrugs. More generally, to rationalize bioactivities, correlations are required, not with the incubation concentration or overall intracellular location, but ideally with the concentration at a specific location.

We thank Ecole Normale Supérieure Paris Saclay for EM's PhD fellowship, TGE RENARD (FR 3443 and UMR8601) and S. Lajnef for access to the EPR spectrometer, Dr J. L. Guerquin-Kern, Dr S. Trepout and Dr T.-D. Wu, for help in cryofixed samples 
preparation, Dr F. Lambert for help in synthesis, Z. Gueroui and S. Clède for help with the fluorescence microscopy, B. Goetz for help with ICP-MS, Pr. A. Leturque and M. Moreau for access to the WES, Dr G. Sommeria-Klein and Dr A. Tebo for useful discussions. Association François Aupetit, ANR (ANR-10IDEX-0001-02 PSL* and ANR-15-CE07-0027), Fondation pour la Recherche Biomédicale (DIE20151234413) are acknowledged for financial support; the SOLEIL and APS committees for beamtime. Use of the Advanced Photon Source, an Office of Science User Facility operated for the U.S. Department Of Energy Office of Science by Argonne National Laboratory, was supported by the U.S. DOE under Contract No. DE-AC02-06CH11357.

\section{Conflicts of interest}

P. S. declares consulting fees, grants, or sponsored travel from Takeda, Abbvie, Merck-MSD or Biocodex. These COI are not related with the present work.

\section{Notes and references}

1 J. J. Soldevila-Barreda and P. J. Sadler, Curr. Opin. Chem. Biol., 2015, 25, 172-183.

2 C. Policar, in Redox Active Therapeutics, ed. J. S. Reboucas, I. BatinicHaberle, I. Spasojevic, D. S. Warner and D. S. Clair, Springer, 2016, ch. 17 , pp. 125-164.

3 S. Miriyala, I. Spasojevic, A. Tovmasyan, D. Salvemini, Z. Vujaskovic, D. St. Clair and I. Batinic-Haberle, Biochim. Biophys. Acta, 2012, 794-814.

4 D. Salvemini, C. Muscoli, D. P. Riley and S. Cuzzocrea, Pulm. Pharmacol. Ther., 2002, 15, 439-447.

5 I. Batinic-Haberle, A. Tovmasyan, E. R. Roberts, Z. Vujaskovic, K. W. Leong and I. Spasojevic, Antioxid. Redox Signaling, 2014, 20, 2372-2415.

6 I. Batinić-Haberle, J. S. Rebouças and I. Spasojević, Antioxid. Redox Signaling, 2010, 13, 877-918.

7 O. Iranzo, Bioorg. Chem., 2011, 39, 73-87.

8 A. Haber and Z. Gross, Chem. Commun., 2015, 51, 5812-5827.

9 D. Salvemini, Z.-Q. Wang, J. L. Zweier, A. Samouilov, H. Macarthur, T. P. Misko, M. G. Currie, S. Cuzzocrea, J. A. Sikorski and D. P. Riley, Science, 1999, 286, 304-305.

10 R. Bonetta, Chem. - Eur. J., 2018, 24, 5032-5041.

11 Y. Sheng, I. A. Abreu, D. E. Cabelli, M. J. Maroney, A.-F. Miller, M. Teixeira and J. S. Valentine, Chem. Rev., 2014, 114, 3854-3918.

12 J. E. Gleason, A. Galaleldeen, R. L. Peterson, A. B. Taylor, S. P. Holloway, J. Waninger-Saroni, B. P. Cormack, D. E. Cabelli, P. J. Hart and V. C. Culotta, Proc. Natl. Acad. Sci. U. S. A., 2014, 111, 5866-5871.

13 R. L. McNaughton, A. R. Reddi, M. H. S. Clement, A. Sharma, K. Barnese, L. Rosenfeld, E. Butler Gralla, J. S. Valentine, V. C. Culotta and B. Hoffman, Proc. Natl. Acad. Sci. U. S. A., 2010, 107, 15335-15339.

14 M. Schieber and N. S. Chandel, Curr. Biol., 2014, 24, R453-R462.

15 A. Ferri, M. Cozzolino, C. Crosio, M. Nencini, A. Casciati, E. B. Gralla, G. Rotilio, J. S. Valentine and M. T. Carri, Proc. Natl. Acad. Sci. U. S. A., 2006, 103, 13860-13865.

16 L. Kruidenier, I. Kuiper, W. van Duijn, S. L. Marklund, R. A. van Hogezand, C. B. H. W. Lamers and H. W. Verspaget, J. Pathol., 2003, 201, 7-16.

17 I. Batinic-Haberle and I. Spasojevic, Antioxid. Redox Signaling, 2014, 20, 2323-2325.
18 E. Mathieu, A.-S. Bernard, N. Delsuc, E. Quévrain, G. Gazzah, B. Lai, F. Chain, P. Langella, M. Bachelet, J. Masliah, P. Seksik and C. Policar, Inorg. Chem., 2017, 56, 2545-2555.

19 A.-S. Bernard, C. Giroud, H. Y. V. Ching, A. Meunier, V. Ambike, C. Amatore, M. Guille Collignon, F. Lemaître and C. Policar, Dalton Trans., 2012, 41, 6399-6403.

20 A. Vincent, J. R. Fores, E. Tauziet, E. Quévrain, A. Dancs, A. ConteDaban, A.-S. Bernard, P. Pelupessy, K. Coulibaly, P. Seksik, C. Hureau, K. Selmeczi, C. Policar and N. Delsuc, Chem. Commun., 2020, 56, 399-402.

21 C. Lenoir, C. Sapin, A. H. Broquet, A.-M. Jouniaux, S. Bardin, I. Gasnereau, G. Thomas, P. Seksik, G. Trugnan, J. Masliah and M. Bachelet, Life Sci., 2008, 82, 519-528.

22 N. Apostolova and V. M. Victor, Antioxid. Redox Signaling, 2015, 22, 686-729.

23 R. A. J. Smith, R. C. Hartley and M. P. Murphy, Antioxid. Redox Signaling, 2011, 15, 3021-3038.

24 M. P. Coogan and V. Fernández-Moreira, Chem. Commun., 2013, 50, 384-399.

25 S. Hostachy, C. Policar and N. Delsuc, Coord. Chem. Rev., 2017, 351, 172-188.

26 S. Clède and C. Policar, Chem. - Eur. J., 2015, 21, 942-958.

27 E. Licandro, M. Panigati, M. Salmain and A. Vessières, in Bioorganometallics: Biomolecules, labeling, medecine, ed. G. Jaouen, Wiley-VCH, Weinheim, 2015, vol. 1, pp. 341-391.

28 K. Barnese, E. Butler Gralla, J. S. Valentine and D. E. Cabelli, Proc. Natl. Acad. Sci. U. S. A., 2012, 109, 6892-6897.

29 K. Barnese, E. B. Gralla, D. E. Cabelli and J. S. Valentine, J. Am. Chem. Soc., 2008, 130, 4604-4606.

30 I. Kenkel, A. Franke, M. Dürr, A. Zahl, C. Dücker-Benfer, J. Langer, M. R. Filipović, M. Yu, R. Puchta, S. R. Fiedler, M. P. Shores, C. R. Goldsmith and I. Ivanović-Burmazović, J. Am. Chem. Soc., 2017, 139, 1472-1484.

31 S. Signorella, C. Palopoli and G. Ledesma, Coord. Chem. Rev., 2018, $365,75-102$.

32 I. Batinic-Haberle, A. Tovmasyan and I. Spasojevic, Antioxid. Redox Signaling, 2018, 29, 1691-1724.

33 J. B. Aitken, E. L. Shearer, N. M. Giles, B. Lai, S. Vogt, J. S. Reboucas, I. Batinic-Haberle, P. A. Lay and G. I. Giles, Inorg. Chem., 2013, 52, 4121-4123.

34 C. M. Weekley, I. Kenkel, R. Lippert, S. Wei, D. Lieb, T. Cranwell, J. L. Wedding, A. S. Zillmann, R. Rohr, M. R. Filipovic, I. IvanovićBurmazović and H. H. Harris, Inorg. Chem., 2017, 56, 6076-6093.

35 K. Valko, J. Chromatogr. A, 2004, 1037, 299-310.

36 F. Cisnetti, A. S. Lefevre, R. Guillot, F. Lambert, G. Blain, E. AnxolabéhèreMallart and C. Policar, Eur. J. Inorg. Chem., 2007, 4472-4480.

37 H. Y. V. Ching, I. Kenkel, N. Delsuc, E. Mathieu, I. IvanovićBurmazović and C. Policar, J. Inorg. Biochem., 2016, 160, 172-179.

38 D. Meyerstein, Coord. Chem. Rev., 1999, 185-186, 141-147.

39 E. K. Barefield, Coord. Chem. Rev., 2010, 254, 1607-1627.

40 A. Conte-Daban, V. Ambike, R. Guillot, N. Delsuc, C. Policar and C. Hureau, Chem. - Eur. J., 2018, 24, 5095-5099.

41 F. C. Friedel, D. Lieb and I. Ivanovic-Burmazovic, J. Inorg. Biochem., 2012, 109, 26-32.

42 Q. Jin, T. Paunesku, B. Lai, S.-C. Gleber, S. Chen, L. Finney, D. Vine, S. Vogt, G. Woloschak and C. Jacobsen, J. Microsc., 2017, 265, 81-93.

43 C. J. Fahrni, Curr. Opin. Chem. Biol., 2007, 11, 121-127.

44 R. McRae, B. Lai and C. J. Fahrni, Metallomics, 2012, 5, 52-61.

45 I. Rodushkin, E. Engström, A. Stenberg and D. C. Baxter, Anal. Bioanal. Chem., 2004, 380, 247-257.

46 J. F. Valentine and H. S. Nick, Gastroenterology, 1992, 103, 905-912.

47 H. S. Nick, R. J. Rogers and J. M. Monnier, J. Biol. Chem., 2001, 276, 20419-20427.

48 S. H. H. Chan, K. L. H. Wub, L. L. Wang and J. Y. H. Chan, Free Radical Biol. Med., 2005, 39, 603-618. 
Intracellular location matters: Rationalization of the anti-inflammatory activity of a manganese (II) superoxide dismutase mimic complex

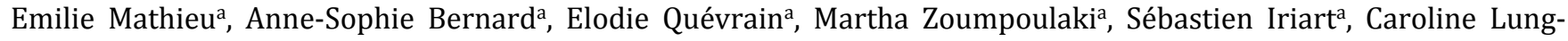
Soong ${ }^{\mathrm{a}}$, Barry Lai ${ }^{\mathrm{b}}$, Kadda Medjoubic, Lucas Henrya ${ }^{\mathrm{a}}$, Sounderya Nagarajan ${ }^{\text {,e }}$, Florent Poyer ${ }^{\mathrm{d}, \mathrm{e}}$, Andreas Scheitler ${ }^{\mathrm{f}}$, Ivana Ivanović-Burmazovićc , Sergio Marco ${ }^{\mathrm{d}, \mathrm{e}}$, Andrea Somogyi ${ }^{\mathrm{c}}$, Philippe Seksiks, Nicolas Delsuc and Clotilde Policar*a

(a) Laboratoire des biomolécules, LBM, Département de chimie, Ecole normale supérieure, PSL University, Sorbonne université, CNRS,75005 Paris, France.E-mail: clotilde.policar@ens.fr

(b) X-ray Science Division, Argonne National Laboratory, Argonne, Illinois 60439, United States.

(c) Synchrotron SOLEIL, BP 48, Saint-Aubin, 91192 Gif sur Yvette, France

(d) Institut Curie, Research Center, PSL University, Chemistry, Modelling and Imaging for Biology (CMIB), Bât 110-112, Centre Universitaire, F-910405 Orsay, France

(e) INSERM U 1196, CNRS UMR 9187, Paris-Saclay University, Paris-Sud University, University Centre, Orsay, France (f) Department of Chemistry and Pharmacy, University of Erlangen-Nürnberg, Egerlandstr. 1, 91058 Erlangen, Germany (g) Sorbonne Université, Ecole normale supérieure, PSL University, CNRS, INSERM, AP-HP, Laboratoire des biomolécules, LBM 75012 Paris, France

1. Materials

2. Supplementary Figures

3. Determination of the intrinsic activity (Fridovich assay and stopped-flow)

4. Synthesis of $\underline{L 2}$

5. Synthesis of $\underline{L 1}$

6. Preparation of the complexes and UV-visible titration

7. Characterization of $\underline{1}$

8. Experiments on HT29-MD2 cells

Cell culture

Cytotoxicity assay

Distribution, and quantification experiments

Quantification of Mn-complexes by EPR in cell lysates

Comparison of EPR and ICP-MS quantification

Quantification of Mn-complexes by ICP-MS in mitochondria-enriched fractions

Infra-red (IR) imaging of $\underline{\mathbf{1}}$

Synchrotron radiation $X$-ray fluorescence microscopy

Evaluation of the biological activity of $\mathrm{Mn}^{2+}$-complexes

9. Supplementary Information References 


\section{Materials}

NMR spectra $\left({ }^{1} \mathrm{H}\right.$ and $\left.{ }^{13} \mathrm{C}\right)$ were recorded on a Bruker DRX300 spectrometer using solvent residual peaks as internal standard. High-resolution mass spectrometry (HRMS) was obtained on a Bruker hybride APEX spectrometer (electrospray) at the ICMMO (Orsay) or on a LTQ FTCIR Thermo electron ionization source ESI. UV-visible spectra were recorded on a Varian Cary 300 Bio spectrophotometer, luminescence emission spectra on a Jasco FP-8300 spectrofluorimeter, and infrared spectra and spectral images on a Cary 620 infrared microscope equipped with a $64 \times 64$ pixels Stingray MCT detector coupled to a Cary 660 spectrometer equipped with a $\mathrm{KBr}$ beamsplitter and a Michelson interferometer. Electrochemistry experiments were performed using an MethrOhm potentiostat (AUTOLAB), and a saturated-calomel reference electrode, glassy carbon working electrode, and a platinum wire counter-electrode from Bio-logic Science instruments (SeyssinetPariset, France). Analytical HPLC measurements were run on a Dionex Ultimate 3000 instrument using C18 ACE® column $(250 \times 4.5 \mathrm{~mm})$ packed with spherical $5 \mu \mathrm{m}$ particles of $300 \AA$ pore size at $1 \mathrm{~mL} \cdot \mathrm{min}^{-1}$. Preparative HPLC consisted of a dual wavelength UV-Vis absorbance detector (Waters 2487) and a Waters 600 preparative pump. Purification of crude product was achieved with a 18 Nucleodur ${ }^{\circledR}$ preparative column $(250 \times 16 \mathrm{~mm}, 5 \mu \mathrm{m}$ particles of $300 \AA$ pore size $)$. Experiments were carried out at a flow rate of $14 \mathrm{~mL} \mathrm{~min}^{-1}$ at room temperature. ICP-MS analyses were performed on an Agilent $7700 \mathrm{X}$. EPR experiments were performed on a Bruker Elexsys 500 spectrometer (Bruker, Wissembourg, France). Fluorescence imaging was performed using an Olympus X71 microscope equipped with a C9100-02 camera (Hamamatsu Corporation, Sewickley, PA), a X60 objective and a Hg lamp (1000W) attenuated by a neutral density filter (ND-1), and confocal fluorescence imaging using a Leica SP5 Confocal laser scanning microscope. X-fluorescence spectromicroscopy samples were manually plunge-frozen using a Leica EM-CPC. Western blot were performed using a capillary-based, automated western blotting system (WES, ProteinSimple, Santa Clara, USA). Stopped-flow measurements were performed on a Biologic SFM-400 four syringe stopped-flow system using only the first three syringes and a Berger Ball mixer to minimize mixing effects between aqueous buffered solutions and DMSO solutions of $\mathrm{KO}_{2}$. A J\&M TIDAS S MMS UV/VIS diode array detector (integration time $0.5 \mathrm{~ms}, 180 \mathrm{~nm}-720 \mathrm{~nm}$ wavelength) and an Energetiq LDLS ENQ EQ-99-FC laser driven light source were used. The ratio between buffer and DMSO solution was kept constant at 9:1. Superoxide solutions were prepared by suspending $220-240 \mathrm{mg} \mathrm{KO}$ in $20 \mathrm{~mL}$ dry DMSO. The suspension was stirred for at least 30 min under inert atmosphere before the suspension was filtered through a PTFE syringe filter $(\varnothing=0.45 \mu \mathrm{m})$ to give a saturated $\mathrm{KO}_{2}$ solution, which was transferred to the stopped flow setup. The buffers were prepared from commercial available 4Morpholinepropanesulfonic acid and Sodium dihydrogen phosphate salts. Buffer concentration was $60 \mathrm{mM}$ and ionic strength was set to $150 \mathrm{mM}$ for each buffer by addition of $\mathrm{NaCl}$. Millipore water was used for all buffer solutions and all buffers were treated with Chelex ${ }^{\circledR} 100$ chelating resin for at least $24 \mathrm{~h}$ before use.

Chemicals and solvents were purchased from commercial sources (Sigma-Aldrich, Alfa-Aesa, Strem, Acros, Iris). LPS (Escherichia coli O55:B5), NADH, NBT, TEMED, riboflavin and pyruvic acid were purchased from Sigma Aldrich (SaintQuentin Fallavier, France). IL8 detection ELISA kit (Duoset) was provided by R\&D Systems (Minneapolis, Minnesota, USA). Mouse monoclonal anti-human COX2, rabbit polyclonal anti-human SOD2 (MnSOD), were from Santa Cruz Biotechnology (Dallas, Texas, USA). BCA and BSA were from Uptima-Interchim (Montluçon, France). Detection ECL system and nitrocellulose membranes were from Amersham Biosciences (Piscataway, New Jersey, USA). Dulbecco's modified Eagle medium (DMEM), and blasticidin, were from Invitrogen (Thermo Fisher Scientific, Waltham, Massachussetts, USA). Fetal bovine serum was from GE Healthcare Life Sciences (South Logan, Utah, USA). HEPES buffer solution (1M), EDTA solution (0.5 M), and Dulbecco's phosphate Buffered Saline (10X, DPBS) were from Gibco (Thermo Fisher Scientific, Waltham, Massachussetts, USA). The protease inhibitor cocktail was from Roche Diagnostics (Meylan, France). Acrylamide-bis-acrylamide was from Q-Biogene (Carlsbad, California, USA). WES reagents were from Protein Simple, rabbit polyclonal anti-actin used for WES was from NOVUS (NB600-50399). Silicon nitride windows were purchased from Agar Scientific. 


\section{Supplementary Figures}

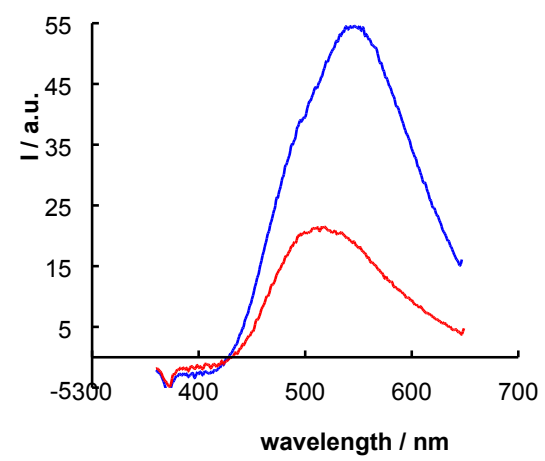

Figure S1 - Emission spectra of $\underline{\mathbf{L} 1}$ (blue) and $\underline{\mathbf{1}}$ (red). Spectra of $\underline{\mathbf{L} 1}$ and $\underline{\mathbf{1}}(100 \mu \mathrm{M}, 0.02 \% \mathrm{DMSO})$ were recorded in HEPES buffer (0.1 M, pH 7.5), with an excitation wavelength of $330 \mathrm{~nm}$.

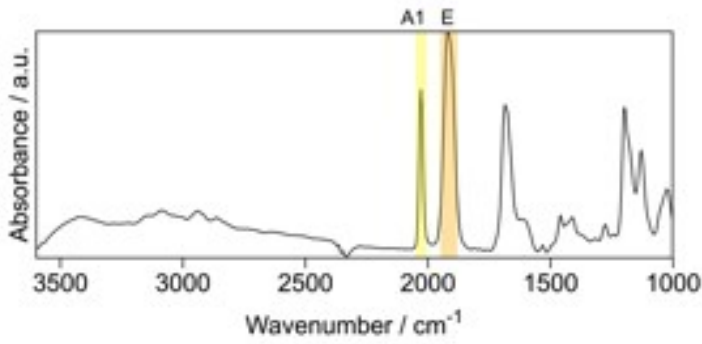

Figure S2 - Infra-red (IR) absorption spectrum of $\underline{\mathbf{L 1}}$. IR-spectrum of $\underline{\mathbf{L 1}}$ (10 mM, 2\%DMSO) in HEPES buffer (0.1 M, pH 7.5) was deposited on a $\mathrm{CaF}_{2}$ membrane and air-dried before measurement. The $\mathrm{A} 1$ and E-bands specific of carbonyl moieties are indicated.
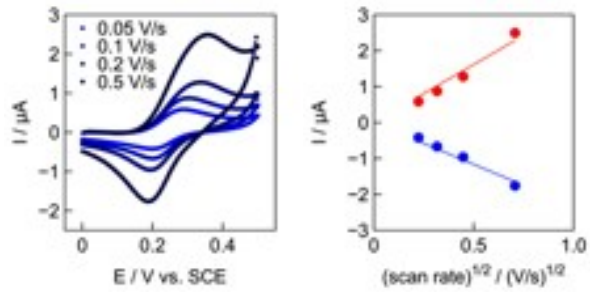

Figure S3 - Cyclic voltammograms (CV) of 1 at varying scan rates, and plots of peak current intensities versus square root of scan rate, and peak potentials versus log of scan rate. $\mathrm{CV}$ of $\underline{1}(100 \mu \mathrm{M}, 0.02 \%$ DMSO) in HEPES $(100 \mathrm{mM}, \mathrm{pH} 7.5, \mathrm{RT})$ were recorded at a glassy carbon disk electrode (3 $\mathrm{mm}$ ) at varying scan rates. Reference electrode, SCE; counter electrode, Pt wire. The capacitive current was subtracted for each voltammogram.. Peak current intensities were plot versus (scan rate) $)^{1 / 2}$ and vary linearly, which assess that the electron transfer is heterogeneous.
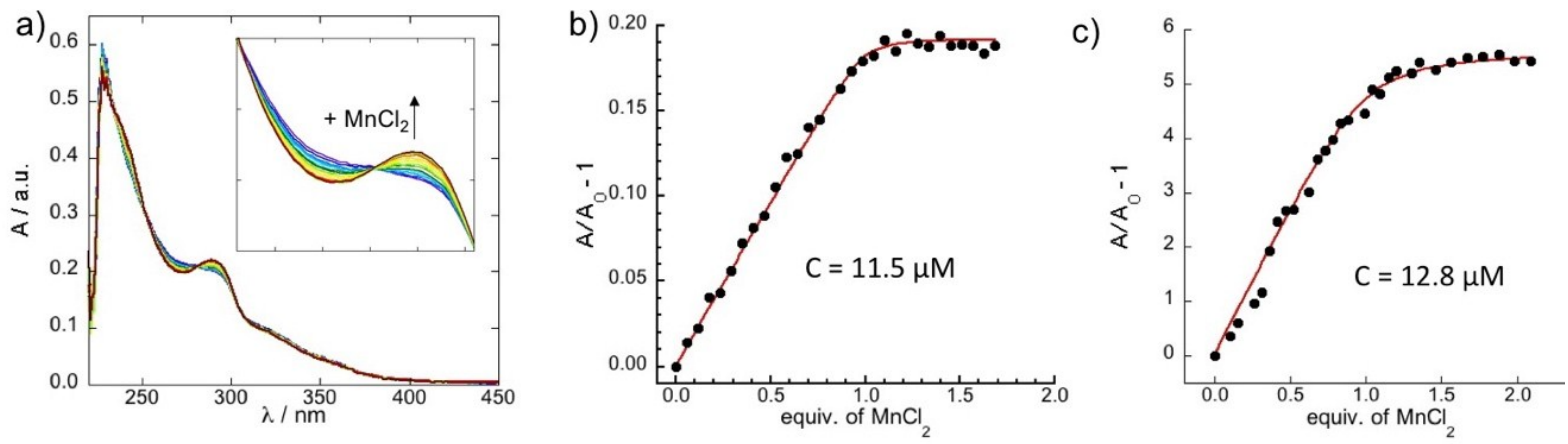

Figure S4 - (a) UV-visible titration of $\underline{\mathbf{L} 1}$ with $\mathbf{M n C l}_{\mathbf{2}}$ (b) Determination of the dissociation constant. $\underline{\mathbf{L} 1}(11,5 \mu \mathrm{M} 0.02 \%$ DMSO) in HEPES (50 mM, $\left.\mathrm{pH} 7.5,25^{\circ} \mathrm{C}\right)$, compared with (c) the determination of the dissociation constants for $\underline{\mathbf{L} 2}$ with $\mathbf{M n C l}_{\mathbf{2}}(12.8 \mu \mathrm{M})$ in $\mathrm{HEPES}\left(50 \mathrm{mM}\right.$, pH $\left.7.5,25^{\circ} \mathrm{C}\right)$, see $\S 7$ for details in the simulation procedure. 


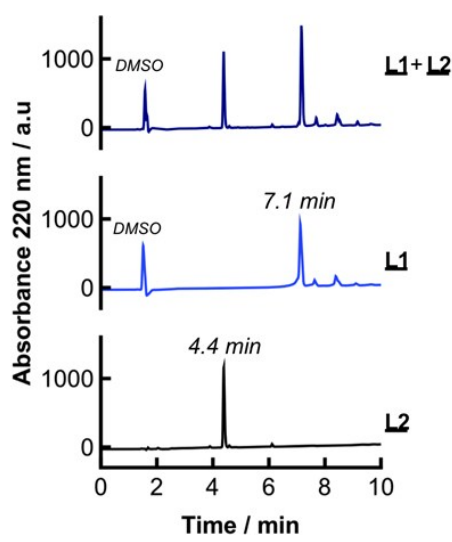

Figure S5 - Comparison of $\underline{\mathbf{L 1}}$ and $\underline{\mathbf{L 2}} \mathbf{2}$ hydrophobicity. Injection of a solution of $\underline{\mathbf{L 1}}, \underline{\mathbf{L 2}}$, or a mixture of both, in water/0.1\% TFA on a C18 column using a gradient of 5 to $70 \%$ ACN $/ 0.1 \%$ TFA in 10 minutes. Stock solution of $\underline{\mathbf{L} 1}$ contains $2 \%$ DMSO. Note that the small peaks at a retention time greater than $7.1 \mathrm{~min}$ are due to exchange of the $\mathrm{Cl}$ ligand in the $\operatorname{Re}(\mathrm{CO})_{3}$ coordination sphere with TFA and water during the HPLC purification.
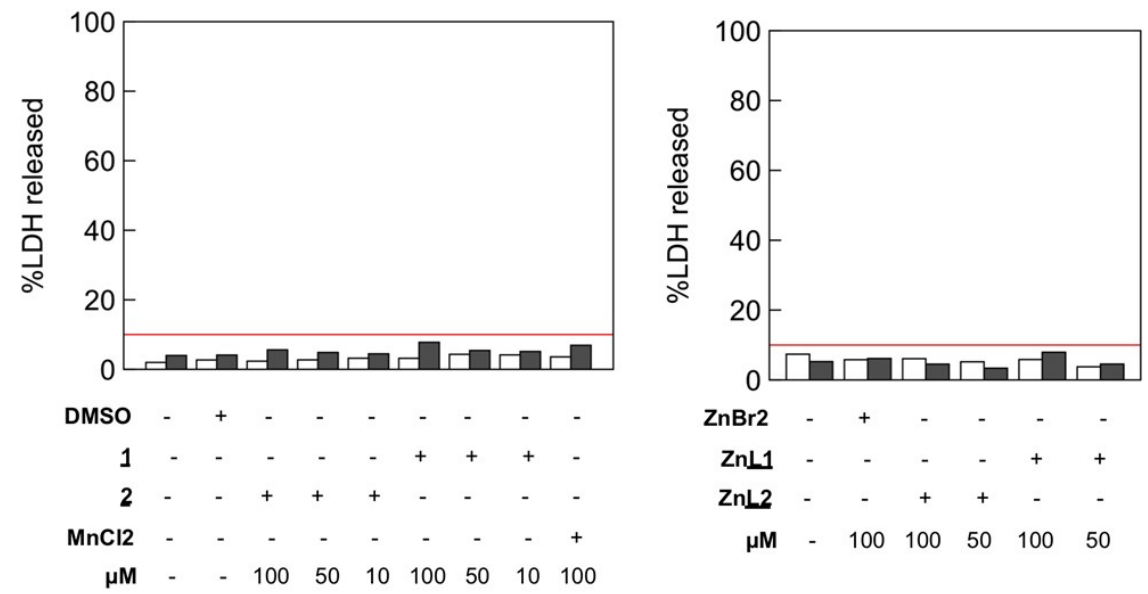

Figure S6 - \%LDH released in activated and non-activated HT29-MD2 cells. Intestinal epithelial cells HT29-MD2 were incubated for 7 hours under different conditions indicated in the figure. LPS $\left(0.1 \mu \mathrm{g} \cdot \mathrm{mL}^{-1}\right)$ was added at the end of the first hour. Left: Incubation with $\underline{\mathbf{1}}$, $\underline{\mathbf{2}}$, $\mathrm{MnCl}_{2}$, or DMSO $(0.02 \%)$ with (gray) or without LPS (white). Right: Incubation with $\mathrm{ZnBr}_{2}, \mathrm{ZnL1}$, or ZnL2 with (gray) or without LPS (white). Stock solution of $\underline{\mathbf{L} 1}$ contains $2 \%$ DMSO. The final concentration of DMSO during the incubation does not exceed $0.02 \%$.
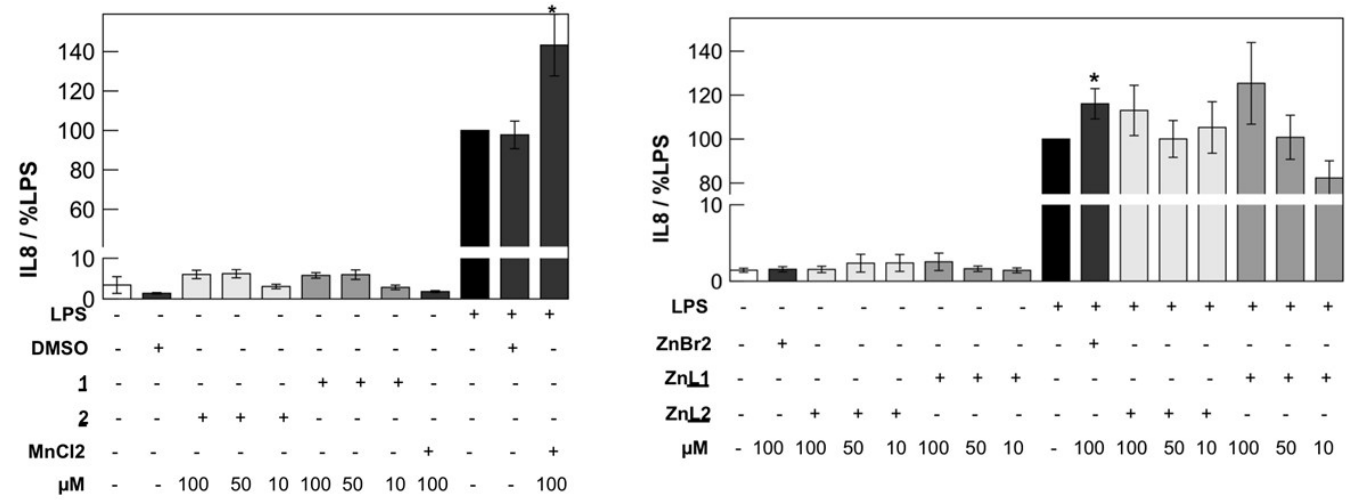

Figure S7 - IL8 secretion in HT29-MD2 cells. Intestinal epithelial cells HT29-MD2 were incubated for 7 hours under different conditions indicated in the figure. LPS $\left(0.1 \mu \mathrm{g} \cdot \mathrm{mL}^{-1}\right)$ was added at the end of the first hour. Left: Incubation with $\underline{\mathbf{1}}, \underline{\mathbf{2}}, \mathrm{MnCl}_{2}$, or $\mathrm{DMSO}(0.02 \%)$ with or without LPS. Data represent means \pm SEM for 7-10 independent experiments. Right: Incubation with $\mathrm{ZnBr}_{2}$, $\mathrm{ZnL1}$, or $\mathrm{ZnL2}$. Stock solution of $\underline{\mathbf{L 1}}$ contains $2 \%$ DMSO. The final concentration of DMSO during the incubation does not exceed $0.02 \%$. Data represent means \pm SEM for $4-5$ independent experiments.

A pro-inflammatory effect of $\mathrm{MnCl}_{2}$ and $\mathrm{ZnBr}_{2}$ is observed (IL8 secretion higher than for LPS-activated cells). 
a.

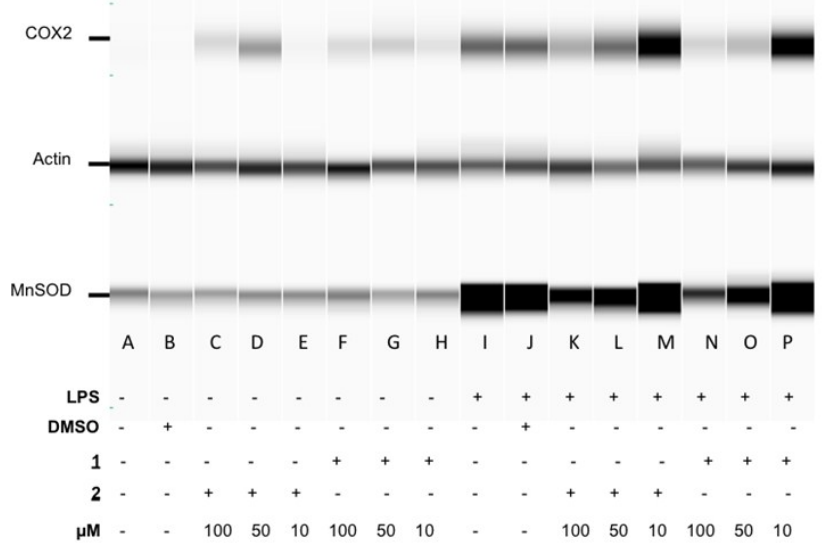

b.
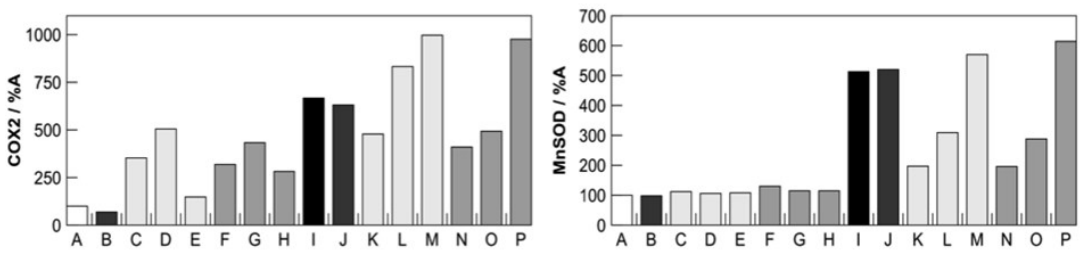

Figure S8 - COX2, MnSOD and actin expression in HT29-MD2 cells. Intestinal epithelial cells HT29-MD2 were incubated for 7 hours under different conditions indicated in the figure. LPS $\left(0.1 \mu \mathrm{g} \cdot \mathrm{mL}^{-1}\right)$ was added at the end of the first hour. a: Detection of COX2, actin, and MnSOD by capillary electrophoresis. b: Plot of the ratio of the band intensities for COX2/actin, and MnSOD/actin as a percentage of A (non-activated cells). Stock solution of enPI ${ }_{2}-\mathrm{RePyta}$ contains $2 \% \mathrm{DMSO}$. The final concentration of DMSO during the incubation does not exceed $0.02 \%$.
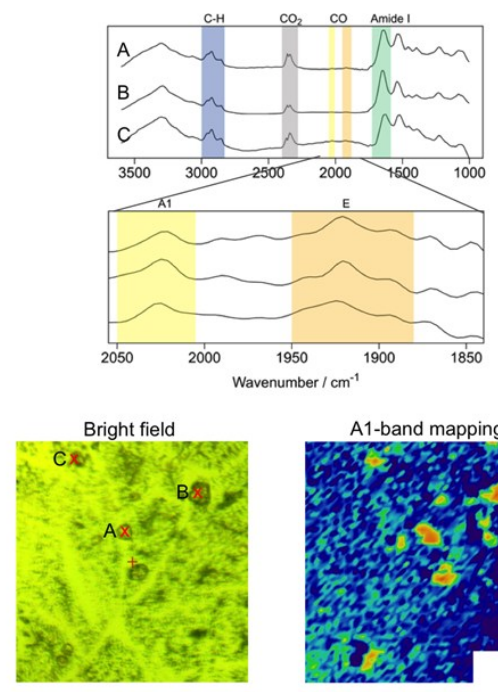

A1-band mapping

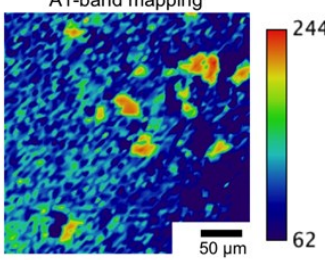

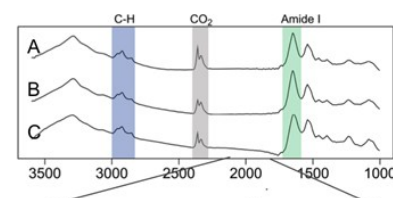

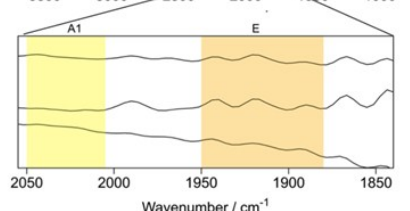

Bright field
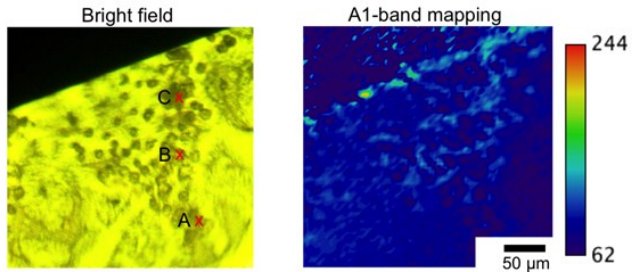

Figure S9 - Infra-red (IR) detection of 1 in cryofixed and freeze-dried HT29-MD2 cells. Left: Transmission IR spectra of HT29-MD2 cells incubated with $1(100 \mu \mathrm{M}, 0.02 \% \mathrm{DMSO})$ for 6 hours before cryofixation and freeze-drying. Spectrum at different positions showing A1 and Ebands characteristic of carbonyl group coordinated to Re. Bright-field, and FTIR-SM image based on the integration of A1-band (2055-2005 cm$\left.{ }^{1}\right)$; 256 scans, $8 \mathrm{~cm}^{-1}$ spectral width. Right: Transmission IR spectra of HT29-MD2 cells cryofixed and freeze-dried. Bright-field and FTIR-SM image based on the integration of A1-band (2055-2005 $\left.\mathrm{cm}^{-1}\right) ; 256 \mathrm{scans}, 8 \mathrm{~cm}^{-1}$ spectral width. No signal for the carbonyl group is detected on the IR spectra recorded on cells. Scale bar, $50 \mu \mathrm{m}$. 
a.
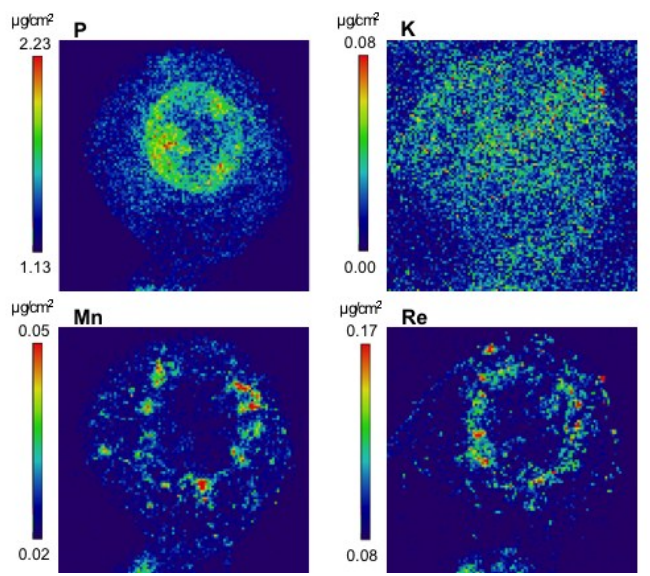

$\mu \mathrm{gm}^{2} \mathrm{Re}$
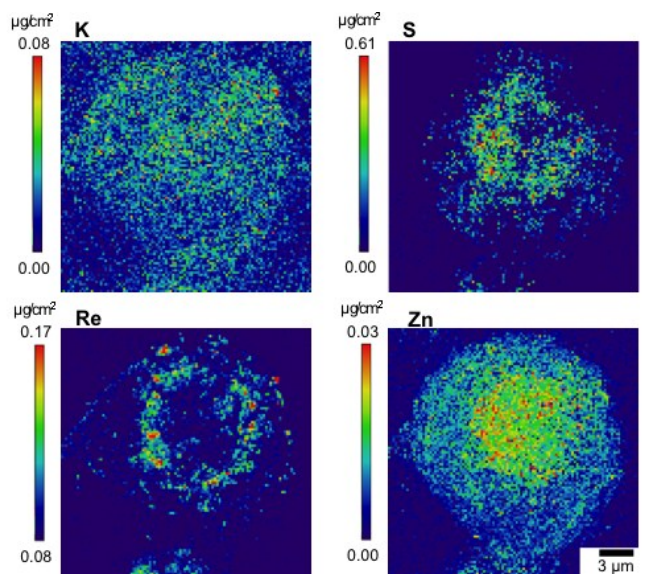

$\mu \mathrm{gam}^{2} \mathrm{Zn}$
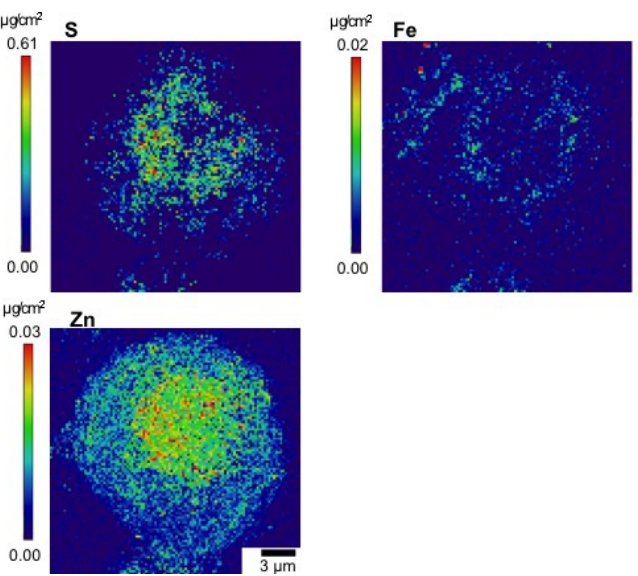

b.
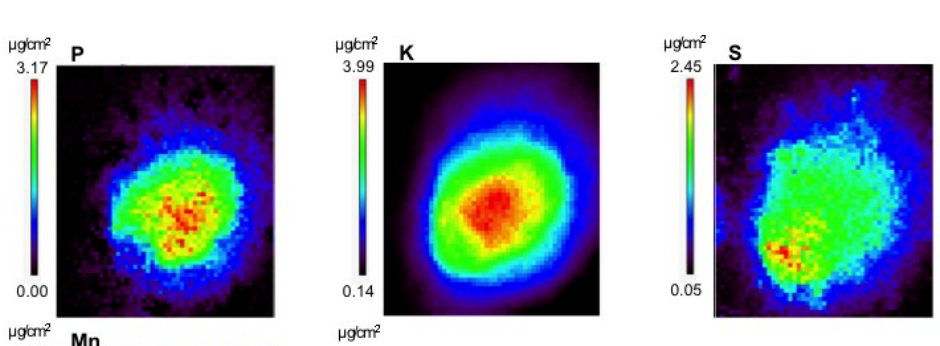

gim

0.05

0.

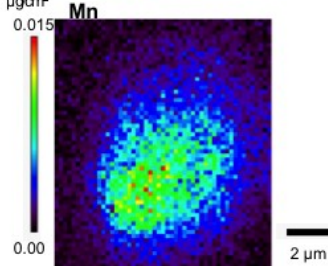

Figure S10 - Elemental distribution of $\mathrm{P}, \mathrm{K}, \mathrm{S}, \mathrm{Fe}, \mathrm{Mn}, \mathrm{Re}$, and $\mathrm{Zn}$ in a HT29-MD2 cell incubated with $\underline{1}$ (a), and a control cell (b). The phosphorus $(\mathrm{P})$ and zinc $(\mathrm{Zn})$ maps are used to identify the nucleus area. a: Intestinal epithelial cells HT29-MD2 were incubated for 2 hours with $\underline{\mathbf{1}}$ (100 $\mu \mathrm{M}$, $0.02 \% \mathrm{DMSO}$ ) before washing with $50 \mathrm{mM}$ EDTA, cryofixation and freeze-drying. Images were recorded on the 2-ID-D beamline of APS synchrotron (excitation at $12.0 \mathrm{keV}$; integration time, $2 \mathrm{~s} /$ pixel; pixel size, $200 \mathrm{~nm}$ ). Scale bar, $3 \mu \mathrm{m}$; b: Control cell. Images were recorded on the 2-ID-D beamline of APS synchrotron (excitation $6.8 \mathrm{keV}$; integration time, $2 \mathrm{~s} /$ pixel; pixel size, $200 \mathrm{~nm}$ ).
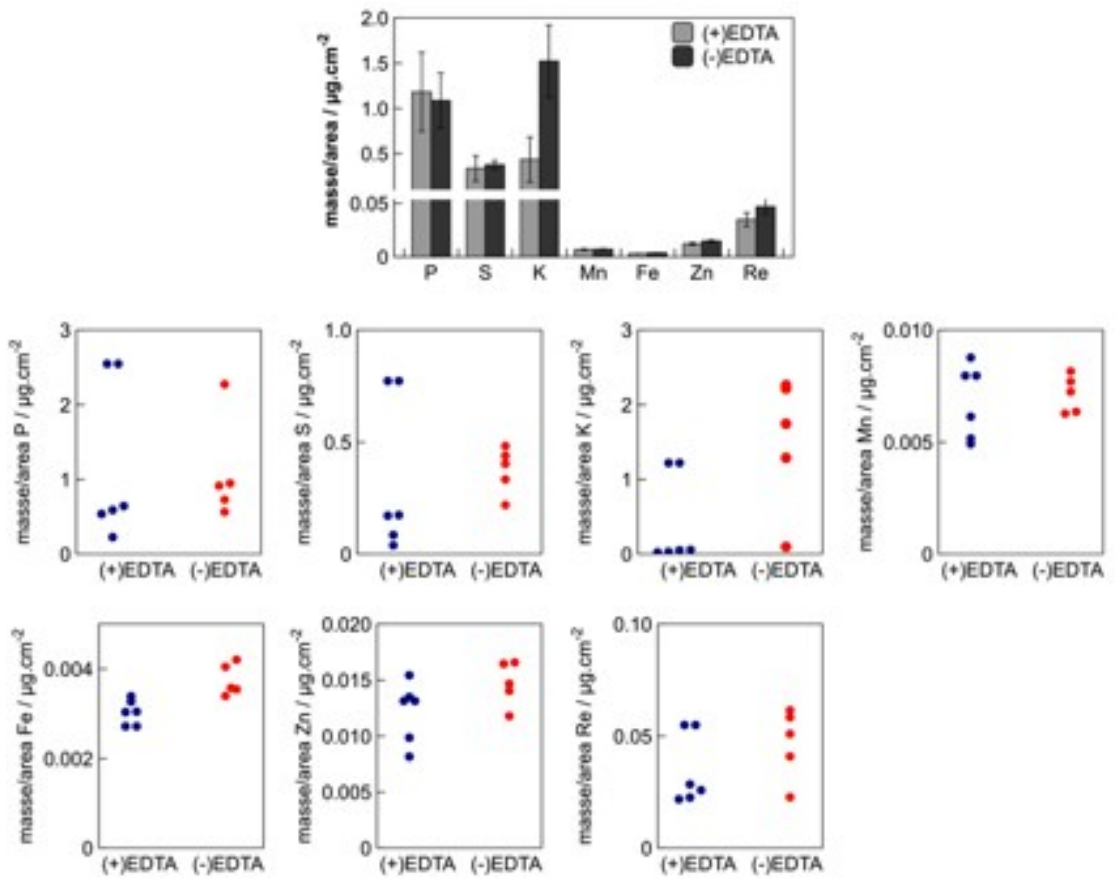

Figure S11 - Quantification of P, S, K, Mn, Fe, Zn, and Re HT29-MD2 cell incubated with 1, with or without EDTA washing. Intestinal epithelial cells HT29-MD2 were incubated for 2 hours with $\underline{1}(100 \mu \mathrm{M}, 0.02 \% \mathrm{DMSO})$ before washing (with or without $50 \mathrm{mM}$ EDTA), cryofixation and freeze- 
drying. The concentrations were obtained by calibration using standards for each element, apart Re. For the latter, no standard is available, the concentration may thus vary by $\pm 50 \%$. Top: Data represent the mean concentration $\left(\mu \mathrm{g} / \mathrm{cm}^{2}\right)$ of each element \pm SEM for $n=5$ or 6 cells $((-)$ EDTA and $(+)$ EDTA respectively). Bottom: Plot of the element concentration $\left(\mu \mathrm{g} / \mathrm{cm}^{2}\right)$ in each cell. Images were recorded on the 2-ID-D beamline of APS synchrotron (excitation at $12.0 \mathrm{keV}$; integration time, $2 \mathrm{~s} /$ pixel; pixel size, $200 \mathrm{~nm}$ ).

The washing with EDTA does not change the concentration of Mn and Re in cells.
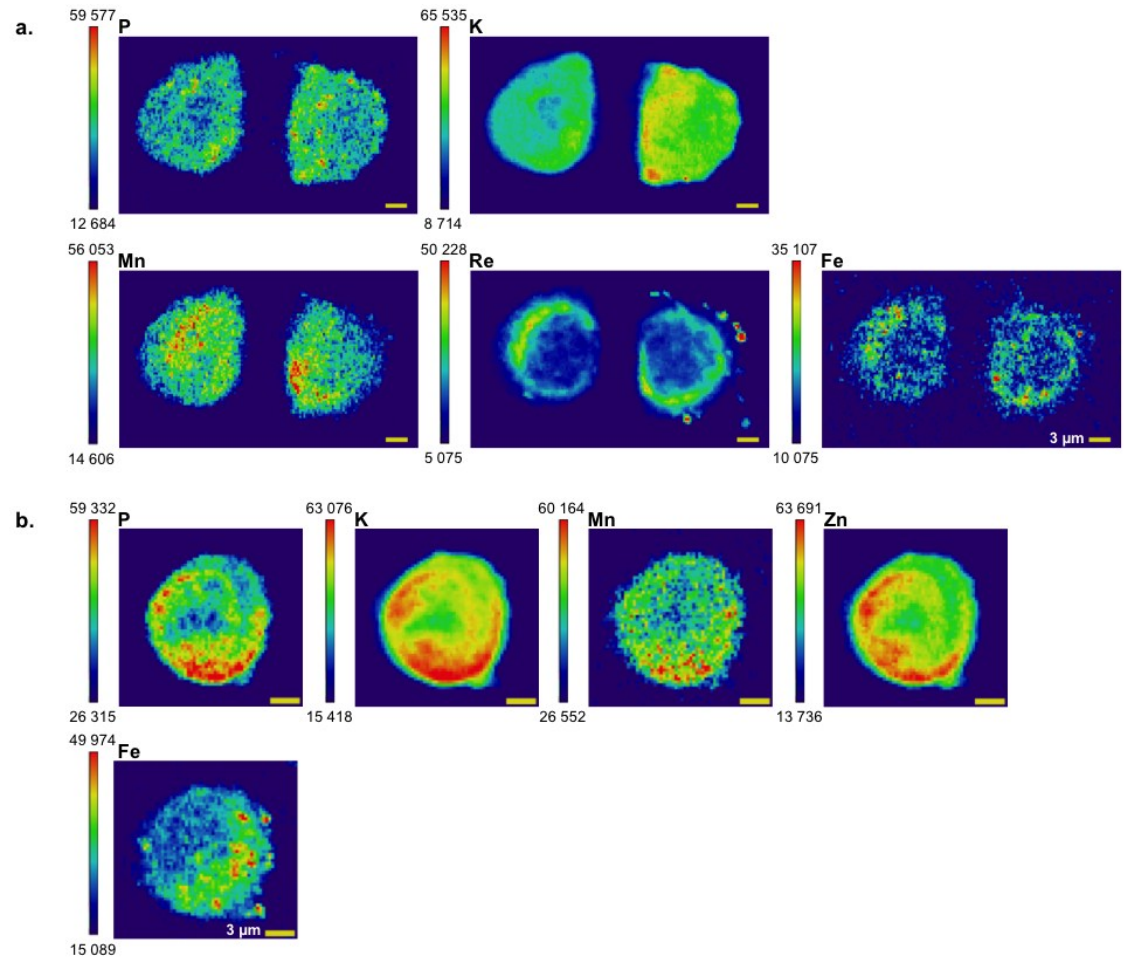

Figure S12 - Elemental distribution in HT29-MD2 cells incubated with 1 (a), and a control cell (b). Intestinal epithelial cells HT29-MD2 were incubated for $1 \mathrm{~h} 30$ with $\underline{\mathbf{1}}(100 \mu \mathrm{M}, 0.02 \% \mathrm{DMSO})$ or medium only (control) before the addition of Mitotracker ${ }^{\mathrm{TM}}$ deep red (200 nM, $\left.30 \mathrm{~min}\right)$, washing with $50 \mathrm{mM}$ EDTA, cryofixation and freeze-drying. Images were recorded on the Nanoscopium beamline of SOLEIL synchrotron. a: excitation at 14.1 $\mathrm{keV}$; integration time, $2.4 \mathrm{~s} /$ pixel; pixel size, $300 \mathrm{~nm}$; b: excitation at $9.9 \mathrm{keV}$; integration time, $2.4 \mathrm{~s} /$ pixel; pixel size, $300 \mathrm{~nm}$. Scale bar, $3 \mu \mathrm{m}$. Intensities were normalized to the maximum intensity value for each element and scaled from 0 to $2^{16}$ (see below).

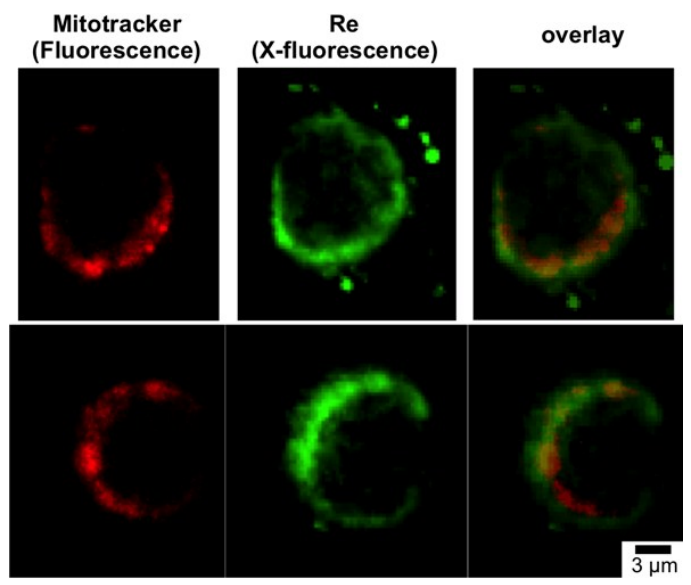

Figure S13 - Confocal fluorescence images of HT29-MD2 cells incubated with a mitochondrial marker (Mitotracker ${ }^{\mathrm{TM}}$, fluorescence) and Xfluorescence maps of $\underline{1}$ (Re, X-fluorescence). Intestinal epithelial cells HT29-MD2 were incubated for $1 \mathrm{~h} 30$ with $\underline{\mathbf{1}}(100 \mu \mathrm{M}, 0.02 \% \mathrm{DMSO})$ before the addition of Mitotracker ${ }^{\mathrm{TM}}$ deep red $(200 \mathrm{nM}, 30 \mathrm{~min})$, washing with $50 \mathrm{mM}$ EDTA, cryofixation and freeze-drying. Confocal fluorescence images of Mitotracker ${ }^{\mathrm{TM}}$ deep red (ex $633 \mathrm{~nm}$, em 645-750 nm) were recorded with open pinhole. X-fluorescence (Re) images were recorded on the Nanoscopium beamline of SOLEIL synchrotron (excitation at $14.1 \mathrm{keV}$; integration time, $2.4 \mathrm{~s} /$ pixel; pixel size, $300 \mathrm{~nm}$ ). Scale bar, $3 \mu \mathrm{m}$.

The overlay shows that part of the Re signal overlap with the Mitotracker ${ }^{\mathrm{TM}}$, suggesting that in these areas $\underline{\mathbf{1}}$ is localized in the mitochondria. This correlates with EPR titration that shows an accumulation of $\mathrm{Mn}$ in these organelles as compared to control cells, but to a lesser extent than Mn1. 
Mn and Re overlay
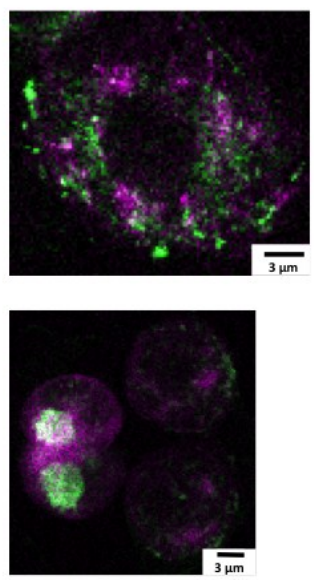

Mn map
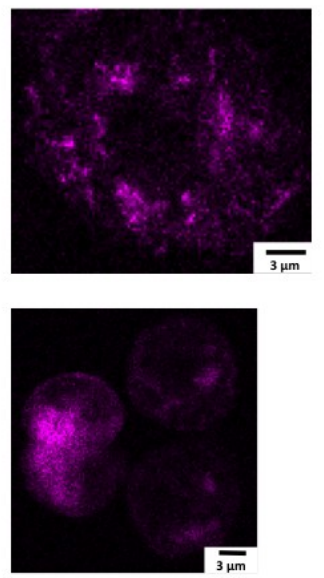

Re map
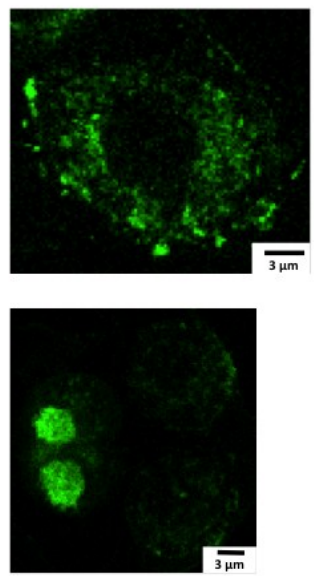

Figure S14. Elemental distribution of Mn, and Re, and overlay of Mn and Re in a HT29-MD2 cell incubated with 1. The overlay corresponds to the Mn (magenta) and Re (L-lines) (green) maps. The regions corresponding to an overlap of both elements are displayed in white. Intestinal epithelial cells HT29-MD2 were incubated for 2 hours with $1(100 \mu \mathrm{M}, 0.02 \% \mathrm{DMSO})$ before EDTA washing, cryofixation and freeze-drying. Images were recorded on the 2-ID-D beamline of APS synchrotron (excitation at $12.0 \mathrm{keV}$; integration time, $2 \mathrm{~s} /$ pixel; pixel size, $200 \mathrm{~nm}$ ).

Mn and Re overlay
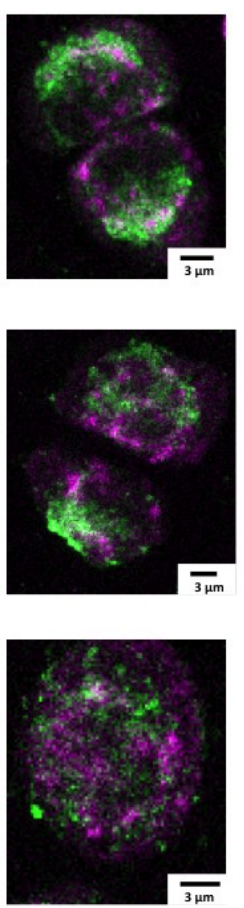

Mn map
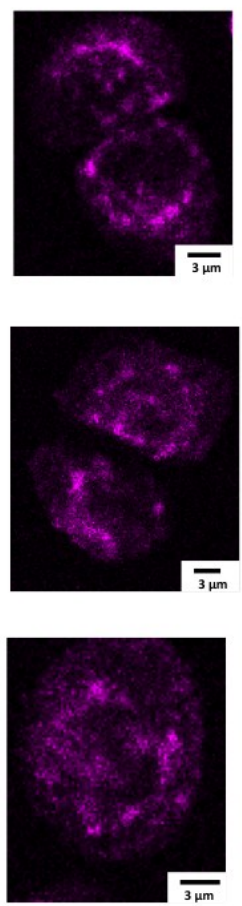

Re map
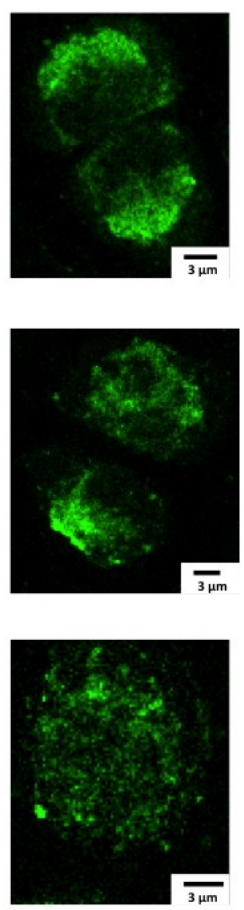

Figure S15. Elemental distribution of Mn, and Re, and overlay of Mn and Re in a HT29-MD2 cell incubated with 1. The overlay corresponds to the Mn (magenta) and Re (L-lines) (green) maps. The regions corresponding to an overlap of both elements are displayed in white. Intestinal epithelial cells HT29-MD2 were incubated for 2 hours with $1(100 \mu \mathrm{M}, 0.02 \% \mathrm{DMSO})$ before cryofixation and freeze-drying. Note that these cells were not washed with EDTA. Images were recorded on the 2-ID-D beamline of APS synchrotron (excitation at $12.0 \mathrm{keV}$; integration time, $2 \mathrm{~s} /$ pixel; pixel size, $200 \mathrm{~nm}$ ). 


\section{Determination of the intrinsic activity (Fridovich assay and stopped-flow)}

The SOD activity of $\underline{\mathbf{1}}$ and $\underline{\mathbf{2}}$ was determined by the McCord-Fridovich assay using the xanthine (200 $\mu \mathrm{M}) /$ xanthine oxidase system to produce superoxide, and ferricytochrome c $(22 \mu \mathrm{M})$ (see Table 1). ${ }^{1-3}$ The SOD activity of $\underline{\mathbf{1}}$ was additionnally determined by stopped-flow measurements (see Table 2). ${ }^{4,5}$

IC50 values represent the concentration at which $50 \%$ of the superoxide reacts with the compound assayed. The constant $\mathrm{k}_{\mathrm{McCF}}$ is determined using the reported $\mathrm{k}_{\mathrm{McCF}}$ for ferricytochrome $\mathrm{c}\left(2.6 \mathrm{x} 10^{5} \mathrm{M}^{-1} \cdot \mathrm{s}^{-1}\right.$ at $\left.\mathrm{pH} 7.8\right) .{ }^{3,6}$ Stock solution of $\underline{\mathbf{L 1}}(10 \mathrm{mM})$ contains $2 \% \mathrm{DMSO}$.

In this assay, superoxide is produced continuously by a xanthine/xanthine oxidase system and reduces ferricytochrome $c$, which is used as superoxide marker. $\mathrm{IC}_{50}$ is the concentration for which the kinetics of the reduction of ferricytochrome $c$ is divided by two. This is also the concentration at which $50 \%$ of the superoxide produced reacted with the compound assayed. From this value, the constant $\mathrm{k}_{\mathrm{McCF}}$ is determined using the relation: ${ }^{1-}$ 3,6

$$
\mathrm{IC}_{50} \times \mathrm{k}_{\mathrm{McCF}}=[\mathrm{cyt} \mathrm{c}] \times \mathrm{k}_{\mathrm{cytc}}
$$

Table S1 - $\mathrm{IC}_{50}$ values determined by McCord-Fridovich assay

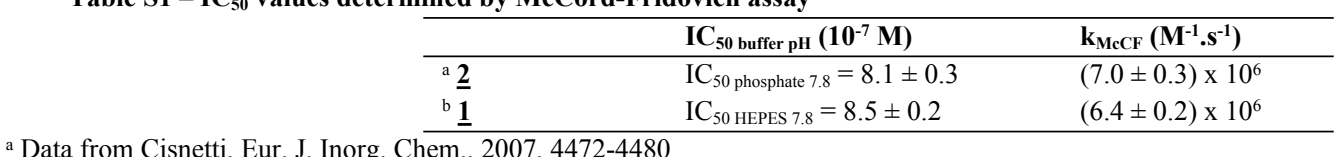

${ }^{a}$ Data from Cisnetti, Eur. J. Inorg. Chem., 2007, 4472-4480

$\mathrm{b}$ This work. Data are given as mean \pm standard deviation for 3 independent experiments.

Table S2 - $\mathbf{k}_{\text {cat }}$ determined by stopped-flow

\begin{tabular}{lll}
\hline & $\mathbf{p H ~ 7 . 4}\left(\mathbf{M}^{-1} \cdot \mathbf{s}^{-1}\right)$ & $\mathbf{p H ~ 7 . 8}\left(\mathbf{M}^{-1} \cdot \mathbf{s}^{-1}\right)$ \\
\hline$\underline{\mathbf{1}}$ & $1.651 \pm 0.010 \times 10^{7}$ & $(6.457 \pm 0.148) \times 10^{6}$ \\
\hline
\end{tabular}

A stock solution $\left(1.00 \times 10^{-4} \mathrm{M}\right)$ of ligand was prepared in each buffer containing $10 \%$ of DMSO and 1 eq. of $\mathrm{MnCl}_{2}$ was added (stock solution) to form the complexes of interest in situ. The complex stock was diluted in buffer to give a series of concentrations suitable for the stopped flow experiments.

Kinetic measurements were performed applying a large excess of superoxide over putative SOD mimetic $\left(\left[\mathrm{O}_{2}{ }^{-}{ }^{-}\right]=100-200\right.$ $\mu \mathrm{M}$ and $[\mathrm{SODm}]=0.25-4.5 \mu \mathrm{M})$. The concentrations were corrected for the $\mathrm{K}_{\text {diss }}(6.1 \pm 0.1) 10^{-7} \mathrm{M}$ of a similar conjugated complex because of the low assaying concentrations. ${ }^{4,5}$ All kinetic data were fitted with the program Biokine 32 V4.80. Each $\mathrm{k}_{\mathrm{obs}}$ value represents an average of at least nine measurements. $\mathrm{k}_{\mathrm{cat}}$ was determined from the slope of $\mathrm{k}_{\mathrm{obs}} \mathrm{vs.}$ [SODm]. All measurements were performed at $21^{\circ} \mathrm{C}$.

\section{Synthesis of $\underline{L 2}$}

$\underline{\mathbf{L 2}}$ was synthesized according to a previously reported procedure. ${ }^{7}$ 


\section{Synthesis of $\underline{L 1}$}

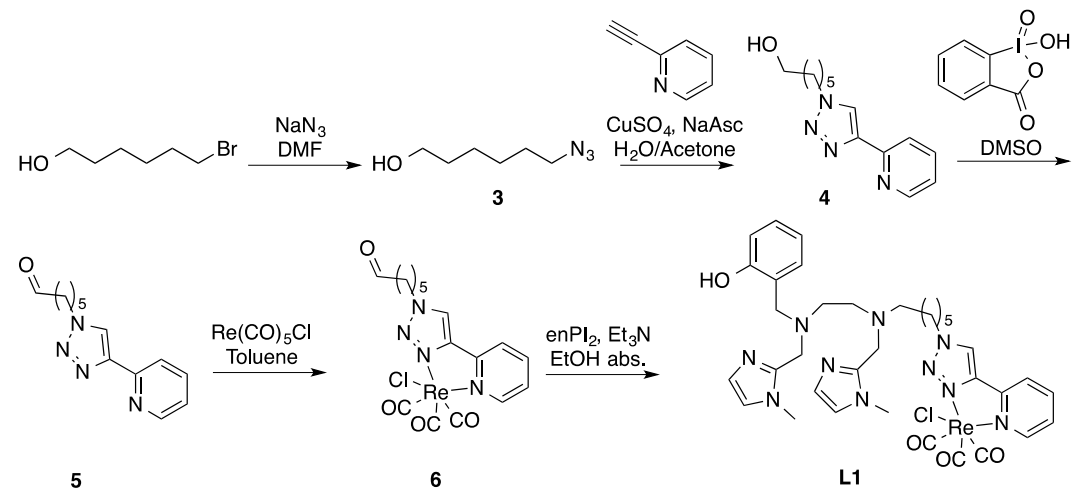

Unless otherwise stated, yields were calculated on the purified product.

\section{6-azidohexan-1-ol ( $(3)$}

To a solution of sodium azide ( $2.0 \mathrm{~g}, 30.6 \mathrm{mmol}, 4 \mathrm{eq})$ in DMF was added 6-bromohexan-1-ol (1.0 mL, $7.6 \mathrm{mmol}, 1 \mathrm{eq})$ at room temperature. The reaction was then stirred at $70{ }^{\circ} \mathrm{C}$ overnight. Water $(20 \mathrm{~mL})$ was added and the aqueous phase was extracted three times with diethyl ether. The organic phase was washed once with brine, dried over anh. $\mathrm{Na}_{2} \mathrm{SO}_{4}$, filtered and concentrated which afforded the desired compound as a colorless oil. Yield: quantitative (1.14 g (7.6 mmol))

${ }^{1} \mathrm{H}$ NMR (300 MHz, Chloroform- $d$ ): $\delta 3.65\left(\mathrm{t}, J=6.5 \mathrm{~Hz}, 2 \mathrm{H}, \mathrm{CH}_{2} \mathrm{OH}\right), 3.27\left(\mathrm{t}, J=6.9 \mathrm{~Hz}, 2 \mathrm{H}, \mathrm{CH}_{2} \mathrm{~N}_{3}\right), 1.60\left(\mathrm{~m}, 4 \mathrm{H}, \mathrm{CH}_{2}\right)$, $1.40\left(\mathrm{~m}, 4 \mathrm{H}, \mathrm{CH}_{2}\right)$.

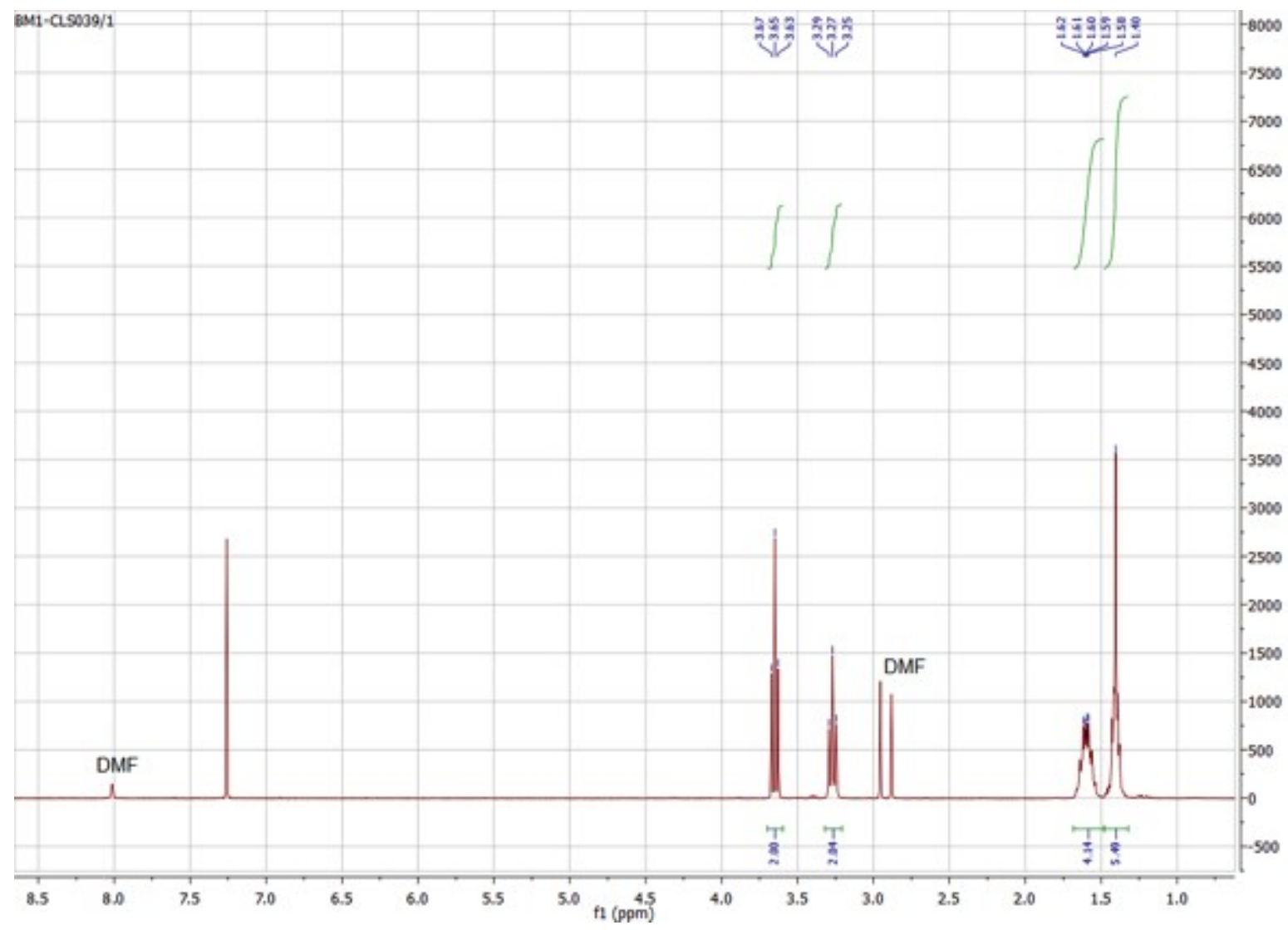




\section{2-(1-hexan-6-ol-1,2,3,triazol-4-yl)-pyridine (ㅁ)}

To a solution of $\underline{\mathbf{3}}(0.593 \mathrm{~g}, 4.15 \mathrm{mmol}, 1 \mathrm{eq})$ in acetone/water $(90 \mathrm{~mL}, 2: 1)$ were added ethynylpyridine $(0.42 \mathrm{~mL}, 4.15$ mmol, 1 eq), copper sulfate $(0.259 \mathrm{~g}, 1.04 \mathrm{mmol}, 0.25 \mathrm{eq})$ and sodium ascorbate $(0.409 \mathrm{~g}, 2.07 \mathrm{mmol}, 0.5 \mathrm{eq})$ at room temperature. The reaction was stirred for $2 \mathrm{~h}$ at room temperature under nitrogen atmosphere and then aqueous ammonia (28 $\% \mathrm{v}: \mathrm{v})$ was added $(50 \mathrm{~mL})$. The aqueous phase was extracted three times with ethyl acetate $(100 \mathrm{~mL})$. The organic phases were combined and dried over anh. $\mathrm{Na}_{2} \mathrm{SO}_{4}$, filtered and concentrated to dryness. The organic fraction was purified by column chromatography $\left(\mathrm{SiO}_{2}, \mathrm{AcOEt} / \mathrm{MeOH} 98: 2,850 \mathrm{~mL}\right)$, affording the product as a white-yellow powder. Yield: $49 \%$ (502 mg (2.02 mmol)).

${ }^{1} \mathrm{H}$ NMR (300 MHz, Chloroform- $d$ ): $\delta 8.57$ (ddd, $\left.J=4.9,1.8,1.0 \mathrm{~Hz}, 1 \mathrm{H}, \mathbf{H}_{\mathbf{p y}}\right), 8.20\left(\mathrm{t}, J=1.1 \mathrm{~Hz}, 1 \mathrm{H}, \mathbf{H}_{\mathbf{p y}}\right), 8.17(\mathrm{~s}, 1 \mathrm{H}$, $\left.\mathbf{H}_{\text {triazole }}\right), 7.78\left(\mathrm{td}, J=7.8,1.8 \mathrm{~Hz}, 1 \mathrm{H}, \mathbf{H}_{\mathrm{py}}\right), 7.23$ (ddd, $\left.J=7.8,4.9,1.8 \mathrm{~Hz}, 1 \mathrm{H}, \mathbf{H}_{\mathrm{py}}\right), 4.43$ (t, $J=7.1 \mathrm{~Hz}, 2 \mathrm{H}, \mathrm{CH}_{2}$-triazol), $3.62\left(\mathrm{t}, J=6.3 \mathrm{~Hz}, 2 \mathrm{H}, \mathrm{CH}_{2} \mathrm{OH}\right), 1.97\left(\mathrm{~m}, 2 \mathrm{H}, \mathrm{CH}_{2}\right), 1.62-1.50\left(\mathrm{~m}, 2 \mathrm{H}, \mathrm{CH}_{2}\right), 1.49-1.30\left(\mathrm{~m}, 4 \mathrm{H}, \mathrm{CH}_{2}\right)$.

${ }^{13} \mathrm{C}$ NMR (75 MHz, Chloroform- $d$ ): $\delta 149.3\left(\mathbf{C H}_{\mathrm{Ar}}\right), 136.9\left(\mathbf{C H}_{\mathrm{Ar}}\right), 130\left(\mathbf{C}_{\mathrm{qAr}}\right), 122.7\left(\mathbf{C H}_{\mathrm{Ar}}\right), 121.7\left(\mathbf{C H}_{\mathrm{Ar}}\right), 120.1\left(\mathbf{C H}_{\mathrm{Ar}}\right)$, $62.3,50.1,32.3,30.1,26.0,25.0\left(\mathrm{CH}_{2}\right)$

HRMS+ (ESI): calcd for $\mathrm{C}_{13} \mathrm{H}_{18} \mathrm{~N}_{4} \mathrm{O}: \mathrm{m} / z$ 269.1376. Found: $\mathrm{m} / z 269.1373$.

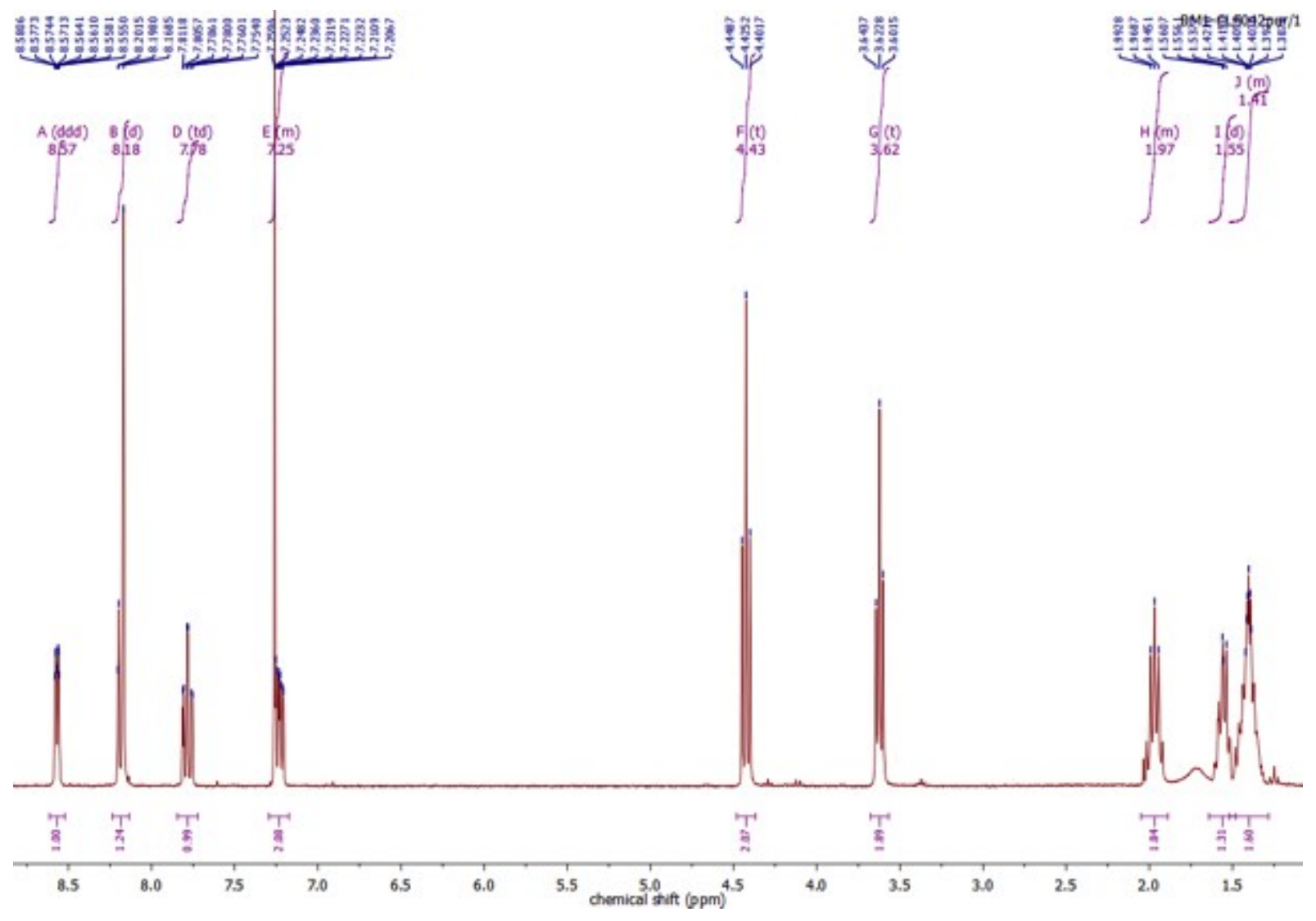




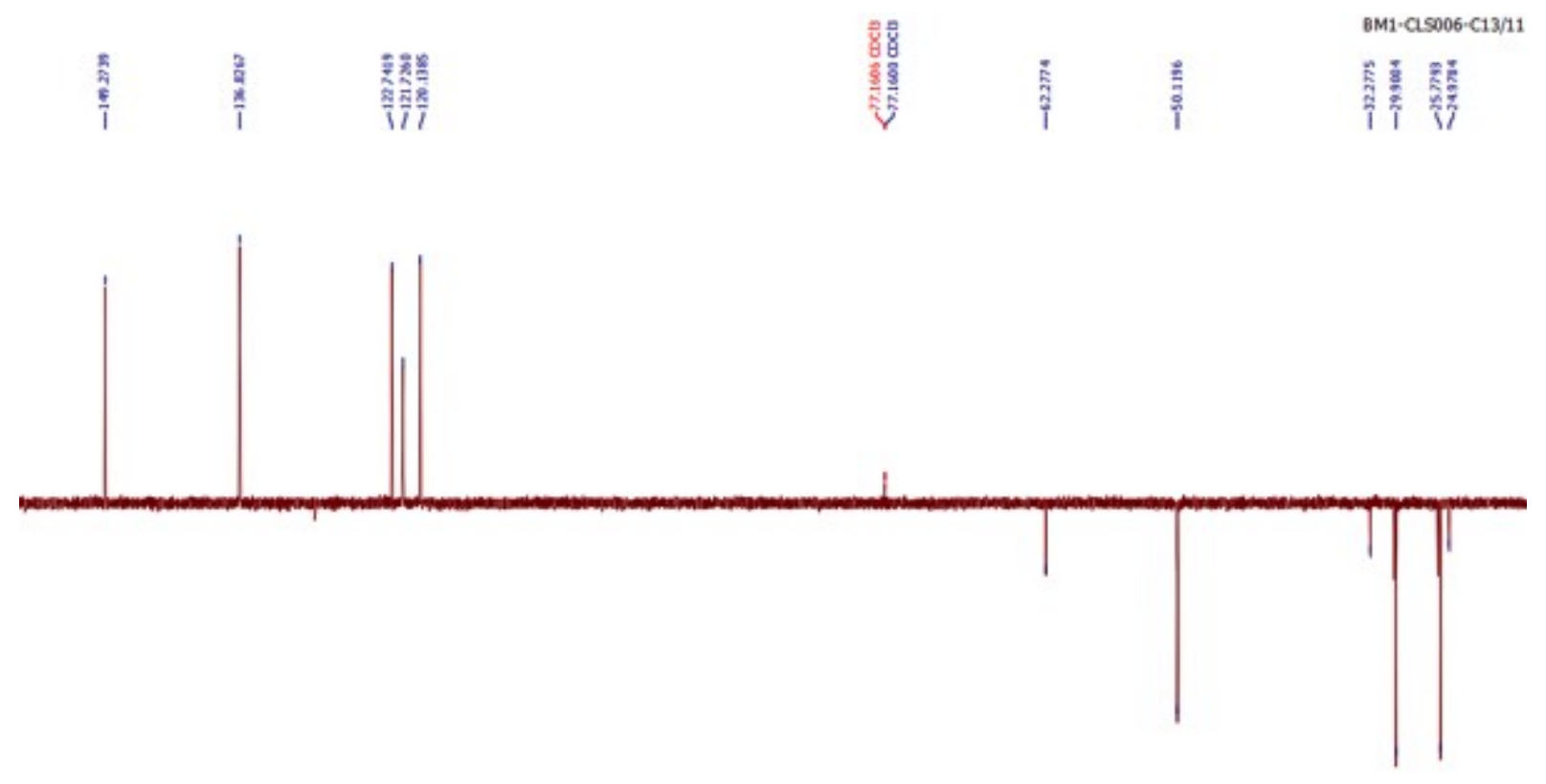

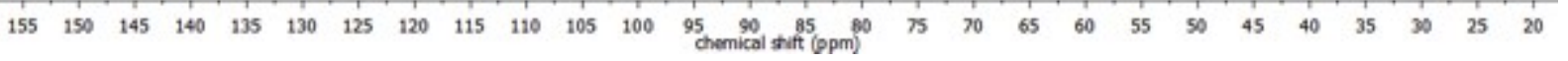

\section{J-mod ${ }^{13}$ C-spectrum}

\section{2-(1-hexanal-1,2,3,triazol-4-yl)-pyridine (ㅍ)}

To a solution of $\underline{4}(253 \mathrm{mg}, 1.02 \mathrm{mmol}, 1 \mathrm{eq})$ in DMSO $(6 \mathrm{~mL})$ was added 2-iodoxybenzoic acid $(0.343 \mathrm{~g}, 1.23 \mathrm{mmol}, 1.2$ eq). The reaction was stirred under nitrogen atmosphere overnight at room temperature. Water $(50 \mathrm{~mL})$ was added and the resulting solution was filtered over a sintered filter and thoroughly washed with ethyl acetate. The organic phase was extracted three times with ethyl acetate, washed with aq. $\mathrm{NaHCO}_{3}$ and brine, dried over anh. $\mathrm{Na}_{2} \mathrm{SO}_{4}$, filtered and concentrated. The desired product appeared as a yellow solid and was used without further purification. Yield: $86 \%$ (213 $\mathrm{mg}$ $(0.87 \mathrm{mmol}))$.

${ }^{1} \mathrm{H}$ NMR (300 MHz, Chloroform- $d$ ): $\delta 9.76(\mathrm{t}, J=1.5 \mathrm{~Hz}, 1 \mathrm{H}, \mathrm{CHO}), 8.58$ (ddd, $\left.J=4.9,1.8,1.1 \mathrm{~Hz}, 1 \mathrm{H}, \mathrm{C} \mathbf{H}_{\mathrm{pyr}}\right), 8.18(\mathrm{dt}, J$ $\left.=8.0,1.1 \mathrm{~Hz}, 1 \mathrm{H}, \mathrm{CH}_{\mathrm{pyr}}\right), 8.12\left(\mathrm{~s}, 1 \mathrm{H}, \mathbf{C H}_{\text {triazole }}\right), 7.78\left(\mathrm{ddd}, J=8.0,7.6,1.8 \mathrm{~Hz}, 1 \mathrm{H}, \mathrm{CH}_{\mathrm{pyr}}\right), 7.23$ (ddd, $J=7.6,4.9,1.1 \mathrm{~Hz}$, $\left.1 \mathrm{H}, \mathrm{CH}_{\mathrm{pyr}}\right), 4.43$ (t, $J=7.0 \mathrm{~Hz}, 2 \mathrm{H}, \mathrm{CH}_{2}$-triazole), 2.45 (td, $\left.J=7.2,1.5 \mathrm{~Hz}, 2 \mathrm{H}, \mathbf{C H}_{2} \mathrm{CHO}\right), 1.99$ (dt, $J=14.8,7.0 \mathrm{~Hz}, 2 \mathrm{H}$, $\left.\mathrm{CH}_{2}\right), 1.68\left(\mathrm{dt}, J=15.1,7.2 \mathrm{~Hz}, 2 \mathrm{H}, \mathrm{CH}_{2}\right), 1.46-1.32\left(\mathrm{~m}, 2 \mathrm{H}, \mathrm{CH}_{2}\right)$.

${ }^{13} \mathrm{C}$ NMR (75 MHz, Chloroform- $d$ ): $\delta 201.8$ (CHO), [149.2, 136.8, 122.7, 121.7, 120.1] $\left(\mathbf{C}_{\mathrm{ar}}\right),[50.0,43.4,30.0,25.9,21.2$, 21.2] $\left(\mathrm{CH}_{2}\right)$.

HRMS+ (ESI): calcd for $\mathrm{C}_{13} \mathrm{H}_{16} \mathrm{~N}_{4} \mathrm{O}: m / z$ 267.1220. Found: $m / z 267.1216$. 

. 


\section{fac-[ $\operatorname{Re}(\mathrm{CO})_{3} \operatorname{Cl}(2-(1-h e x a n a l-1,2,3$, triazol-4-yl)-pyridine $)](\underline{6})$}

To a solution of $\underline{\mathbf{5}}(0.210 \mathrm{~g}, 0.86 \mathrm{mmol}, 1 \mathrm{eq})$ in toluene $(10.5 \mathrm{~mL})$ was added rhenium-pentacarbonyl chloride $(0.311 \mathrm{~g}, 0.86$ mmol, $1 \mathrm{eq}$ ) at room temperature. The reaction was refluxed at $110^{\circ} \mathrm{C}$ for $3 \mathrm{~h}$. After cooling, the solvent was evaporated. The brown solide was purified by column chromatography $\left(\mathrm{SiO}_{2}, \mathrm{EtOAc} / \mathrm{MeOH} 95 / 5,750 \mathrm{~mL}\right)$, affording the pure product as a yellow oil.

Mass: $364 \mathrm{mg}$

Yield: $77 \%$

${ }^{1} \mathrm{H}$ NMR (300 MHz, Chloroform- $d$ ): $\delta 9.79$ (t, $\left.J=1.2 \mathrm{~Hz}, 1 \mathrm{H}, \mathrm{CHO}\right), 9.03\left(\mathrm{~d}, J=5.6 \mathrm{~Hz}, 1 \mathrm{H}, \mathbf{H}_{\mathrm{pyr}}\right), 8.29$ (s, $\left.1 \mathrm{H}, \mathbf{H}_{\text {triazole }}\right)$, $7.98\left(\mathrm{td}, J=7.9,1.5 \mathrm{~Hz}, 1 \mathrm{H}, \mathbf{H}_{\mathrm{pyr}}\right), 7.81\left(\mathrm{~d}, J=7.9 \mathrm{~Hz}, 1 \mathrm{H}, \mathbf{H}_{\mathrm{pyr}}\right), 7.51-7.35\left(\mathrm{~m}, 1 \mathrm{H}, \mathbf{H}_{\mathrm{pyr}}\right), 4.69-4.27\left(\mathrm{~m}, 2 \mathrm{H}, \mathbf{C H}_{2^{-}}\right.$ triazole), $2.62-2.40\left(\mathrm{~m}, 2 \mathrm{H}, \mathrm{CH}_{2} \mathrm{CHO}\right), 2.04\left(\mathrm{t}, J=7.4 \mathrm{~Hz}, 2 \mathrm{H}, \mathrm{CH}_{2}\right), 1.82-1.59\left(\mathrm{~m}, 2 \mathrm{H}, \mathrm{CH}_{2}\right), 1.59-1.31\left(\mathrm{~m}, 5 \mathrm{H}, \mathrm{CH}_{2}\right)$, $1.26(\mathrm{~s}, 1 \mathrm{H})$.

HRMS+ (ESI): calcd for $\mathrm{C}_{17} \mathrm{H}_{21} \mathrm{~N}_{4} \mathrm{O}_{4}$ ClRe: $m / z$ 573.0295. Found: $m / z$ 573.0310.

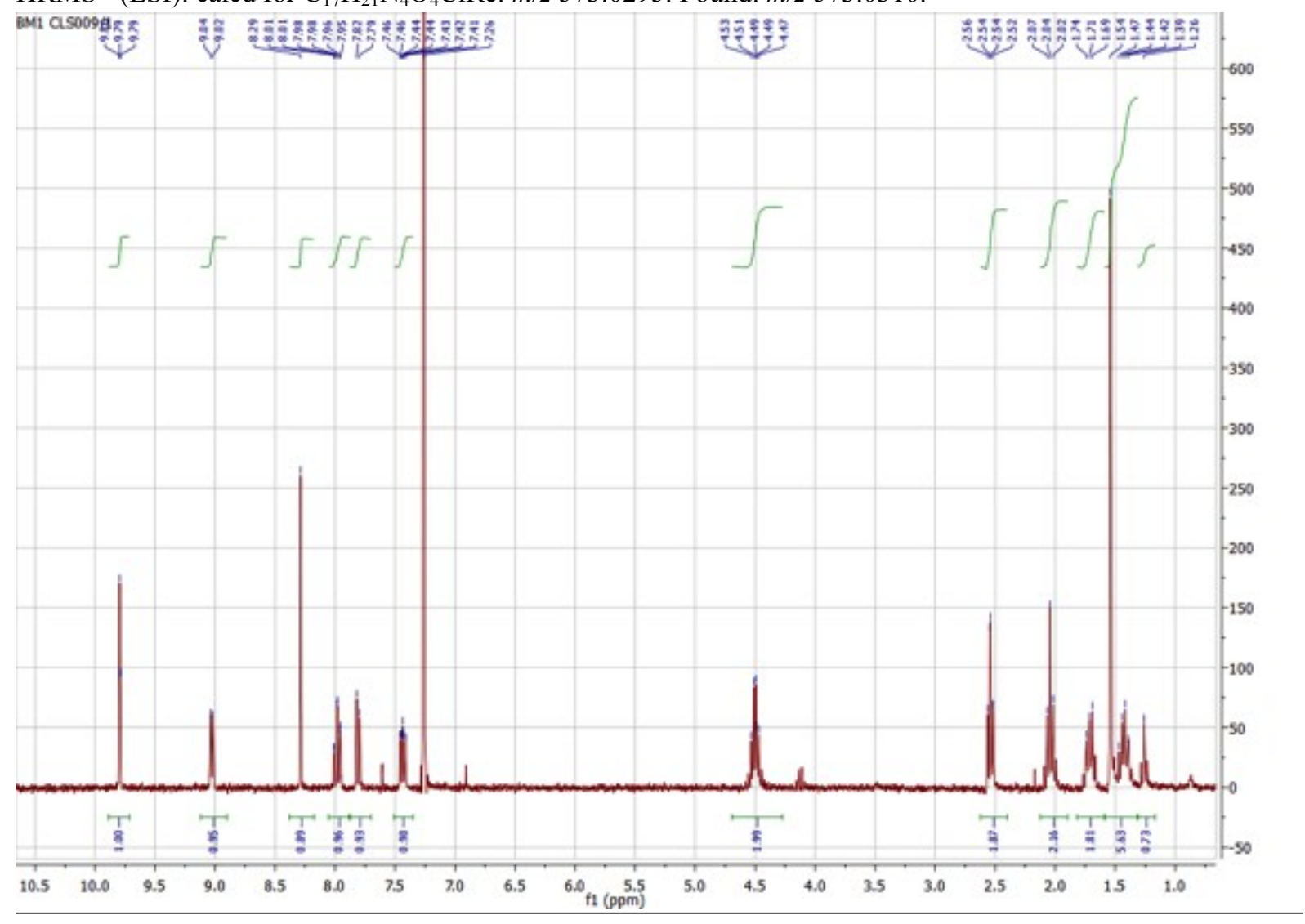

\section{$\underline{\mathbf{L 1}}$}

To a solution of $\underline{\mathbf{L} 2}(298 \mathrm{mg}, 0.51 \mathrm{mmol}, 1 \mathrm{eq})$ in absolute ethanol $(26 \mathrm{~mL})$ was added triethylamine $(70 \mu \mathrm{L}, 0.51 \mathrm{mmol}, 1$ eq) and $\underline{\mathbf{6}}(282 \mathrm{mg}, 0.51 \mathrm{mmol}, 1 \mathrm{eq})$. The reaction was stirred under nitrogen atmosphere overnight. To this solution sodium cyanoborohydride $(77.3 \mathrm{mg}, 1.23 \mathrm{mmol}, 2.4 \mathrm{eq})$ and TFA $(0.08 \mathrm{~mL}, 1.03 \mathrm{mmol}, 2 \mathrm{eq})$ were added, the reaction was stirred overnight. The $\mathrm{pH}$ was set to $8 \pm 0.4$ with a saturated solution of sodium hydrogenocarbonate, and ethanol was evaporated under reduced pressure. Then dichloromethane and water $(4: 1,30 \mathrm{~mL})$ were added and the $\mathrm{pH}$ was set to $9.6 \pm 0.2$. The aqueous phase was extracted three times with dichloromethane and the combined organic fractions were dried upon anh. $\mathrm{Na}_{2} \mathrm{SO}_{4}$, filtered and concentrated. The resulting yellow oil was purified by preparative HPLC (acetonitrile/water + TFA 0.1 $\%$, gradient from 10 to 100 in 30 minutes, $\left.t_{R}=5.9 \mathrm{~min}\right)$. Yield: $26 \%(120 \mathrm{mg})$.

${ }^{1} \mathrm{H}$ NMR (300 MHz, Methanol-d4): $\delta 9.05\left(\mathrm{~d}, J=5.5 \mathrm{~Hz}, 1 \mathrm{H}, \mathbf{H}_{\mathrm{pyr}}\right), 8.96\left(\mathrm{~s}, 1 \mathrm{H}, \mathbf{H}_{\mathrm{pyr}}\right), 8.31-8.11\left(\mathrm{~m}, 2 \mathrm{H}, \mathbf{H}_{\mathrm{ar}}\right), 7.61(\mathrm{t}, J=$ $\left.6.0 \mathrm{~Hz}, 1 \mathrm{H}, \mathbf{H}_{\mathrm{Ar}}\right), 7.51-7.30\left(\mathrm{~m}, 3 \mathrm{H}, \mathbf{H}_{\mathrm{Ar}}\right), 7.19-7.05\left(\mathrm{~m}, 2 \mathrm{H}, \mathbf{H}_{\text {phenol }}\right), 6.88-6.71\left(\mathrm{~m}, 2 \mathrm{H}, \mathbf{H}_{\text {phenol }}\right), 4.63(\mathrm{~m}, 2 \mathrm{H}$, ethane

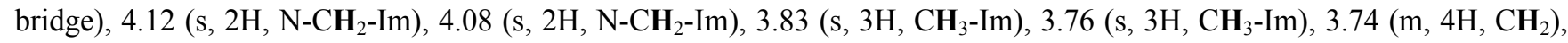
$2.94\left(\mathrm{~m}, 4 \mathrm{H}, \mathrm{CH}_{2}\right), 2.69-2.58\left(\mathrm{~m}, 2 \mathrm{H}, \mathrm{CH}_{2}\right.$-Phenol), 2.01 (m, 2H, ethane bridge), $1.48\left(\mathrm{~m}, 2 \mathrm{H}, \mathrm{CH}_{2}\right), 1.31\left(\mathrm{~m}, 4 \mathrm{H}, \mathrm{CH}_{2}\right)$. 
${ }^{13} \mathrm{C}$ NMR (75 MHz, Methanol-d4): $\delta$ [157.0, 154.8, 151.0, 150.6, 146.0, 142.0, 132.6, 130.7, 127.3, 126.1, 125.4, 125.1, $123.5,121.3,120.8,119.8,116.4]\left(\mathbf{C H}_{\mathrm{Ar}}\right),[55.7,55.5,53.0,52.9,52.6,34.8,30.7,30.6,27.2,26.7,26.4,24.2]\left(\mathbf{C H}_{2}\right)$. HRMS+ (ESI): calcd for $\mathrm{C}_{35} \mathrm{H}_{42} \mathrm{~N}_{10} \mathrm{O}_{4} \mathrm{Re}^{+}: \mathrm{m} / z$ 853.2944. Found: $\mathrm{m} / z$ 853.2943.

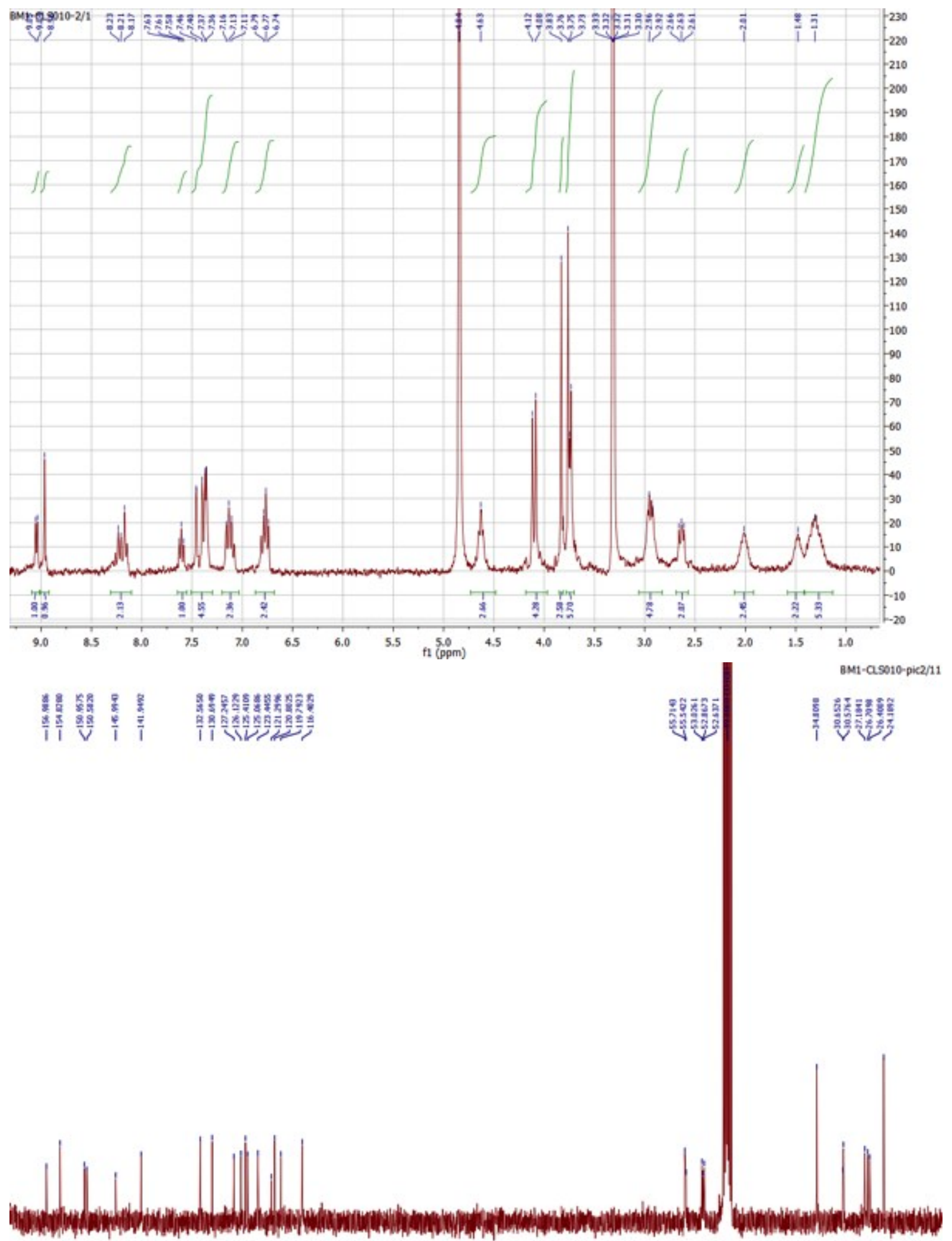

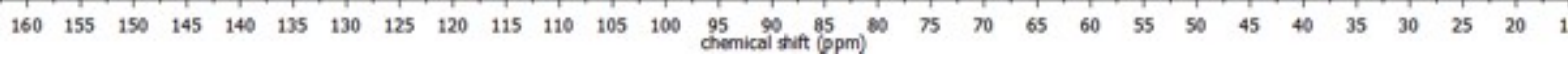

${ }^{13}$ C-spectrum 


\section{Preparation of the complexes and UV-visible titration}

The ligand ( $\underline{\mathbf{L 1}}$, or $\left.\underline{\mathbf{L} \mathbf{2}^{7}}\right)$ was purified by HPLC and lyophilized. $\underline{\mathbf{L} 2}$ was redissolved in milliQ water $\left(80 \mathrm{mg} \cdot \mathrm{mL}^{-1}\right)$. $\underline{\mathbf{L} \mathbf{1}}$ was redissolved in milliQ water containing $2 \%$ DMSO $\left(14 \mathrm{mg} \cdot \mathrm{mL}^{-1}\right)$. An aliquot of the resulting solution was diluted in HEPES buffer $(0.1 \mathrm{M}, \mathrm{pH} 7.5)$ and its concentration was determined by UV-visible titration by successive addition of $\mathrm{MnCl}_{2}(10$ $\mathrm{mM}$ ), by following the absorbance at $280 \mathrm{~nm}$. The titration was performed twice.

The stock solutions of ligand were then filtered on $0.2 \mu \mathrm{m}$ sterile filter and diluted to a concentration of $10 \mathrm{mM}$. Aliquots were prepared and frozen $\left(-20^{\circ} \mathrm{C}\right)$ until used. Stock solution of $\underline{\mathbf{L 1}}$ contains at most $2 \% \mathrm{DMSO}$.

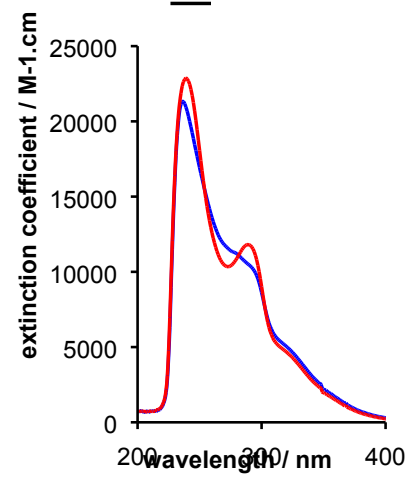

Absorption spectra of $\underline{L 1}$ (blue) and $\underline{1}$ (red)

Stock solutions of $\mathrm{Mn}^{2+}\left(\mathrm{Zn}^{2+}\right)$-complexes at $5 \mathrm{mM}$ were prepared before each experiment by addition of 1.1 eq. of anh. $\mathrm{MnCl}_{2}$ (anh. $\mathrm{ZnBr}_{2}$ ) in HEPES buffer (100 mM, pH 7.4) to a solution of ligand, and then diluted in culture medium at the desired incubation concentration. Note that anhydrous salt were used for a better precision when weighting them.

\section{Characterization of $\underline{1}$}

\section{Emission spectra}

$\underline{\mathbf{L} 1}$ and $\underline{\mathbf{1}}$ were diluted into HEPES buffer $(0.1 \mathrm{M}, \mathrm{pH} 7.5)$ to a concentration of $100 \mu \mathrm{M}$ (containing $0.02 \% \mathrm{DMSO}$ for $\underline{\mathbf{1}}$ ). Excitation wavelength, $330 \mathrm{~nm}$. Emission of the buffer was subtracted.

\section{IR spectra}

A drop of a stock solution of $\underline{\mathbf{L 1}}(10 \mathrm{mM}, 2 \% \mathrm{DMSO})$ in HEPES buffer $(0.1 \mathrm{M}, \mathrm{pH} 7.5)$ was deposited on a $\mathrm{CaF}_{2} \mathrm{membrane}$ and air-dried before measuring the transmission IR spectra.

\section{Electrochemistry}

$\underline{1}$ was diluted into HEPES buffer $(0.1 \mathrm{M}, \mathrm{pH} 7.5)$ at a concentration of $100 \mu \mathrm{M}(0.02 \% \mathrm{DMSO})$. Cyclic voltammograms were measured at different scan rates $(50$ to $500 \mathrm{mV} / \mathrm{s})$. Working electrode, glassy carbon disk ( $3 \mathrm{~mm})$; reference electrode, SCE; counter electrode, $\mathrm{Pt}$ wire. The capacitive current was subtracted for each voltammogram.

\section{HRMS}

HRMS+ (ESI): calcd for $\mathrm{C}_{35} \mathrm{H}_{41} \mathrm{~N}_{10} \mathrm{O}_{4} \mathrm{ReMnCl}^{+}: m / z$ 942.1939. Found: $m / z$ 942.1930.

\section{Determination of the association constants}

Association constants were measured by using UV-vis spectrometry. Titration experiments were performed in HEPES (50 $\mathrm{mM}, \mathrm{pH} 7.5$ ) at $25^{\circ} \mathrm{C}$. Anhydrous $\mathrm{MnCl}_{2}$ dissolved in milliQ $\mathrm{H}_{2} \mathrm{O}$ was added to a solution of the ligand at ca $10 \mu \mathrm{M}$ in 1.5 $\mathrm{mL}$ quartz cuvettes.

For 1, the absorbance at $330 \mathrm{~nm}$ was subtracted from the absorbance at $288 \mathrm{~nm}$ (characteristic of the Mn complex formation).

For 2 , the absorbance at $320 \mathrm{~nm}$ was subtracted from the absorbance at $288 \mathrm{~nm}$.

Experiments were performed at least in duplicate.

During the titration, one equilibrium is considered: 


\begin{tabular}{|l|l|l|}
\hline \multicolumn{2}{|c|}{$\mathrm{L}+\mathrm{MnCl}_{2} \quad=$} & \multicolumn{1}{c|}{ complex } \\
\hline$C_{0}$ & $n_{\text {equiv. }} * C_{0}$ & 0 \\
\hline$C_{0} *(1-X)$ & $\left(n_{\text {equiv. }}-X\right) * C_{0}$ & $X * C_{0}$ \\
\hline
\end{tabular}

So the association constant can be written:

$$
\begin{aligned}
K_{\text {ass }} & =\frac{X * C_{0}}{\left(n_{\text {equiv. }}-X\right) * C_{0} * C_{0} *(1-X)} \\
K_{\text {ass }} & =\frac{X}{\left(n_{\text {equiv. }}-X\right) * C_{0} *(1-X)}
\end{aligned}
$$

Which gives the second-degree equation to solve: $\mathrm{aX}^{2}+\mathrm{bX}+\mathrm{c}=0$

$X^{2}-X *\left(1+n_{\text {equiv. }}+\frac{1}{K_{\text {ass }} * C_{0}}\right)+n_{\text {equiv. }}=0$

$\Delta=\left(1+n_{\text {equiv. }}+\frac{1}{K_{\text {ass }} * C_{0}}\right)^{2}-4 * n_{\text {equiv. }}$

$X=\frac{1+n_{\text {equiv. }}+\frac{1}{K_{\text {ass }} * C_{0}}-\sqrt{\left(1+n_{\text {equiv. }}+\frac{1}{K_{\text {ass }} * C_{0}}\right)^{2}-4 * n_{\text {equiv. }}}}{2}$

Considering the UV experiment,

$A_{288}=\varepsilon_{L} * l * C_{L}+\varepsilon_{\text {complex }} * l * C_{\text {complex }}$

$A_{0}=\varepsilon_{L} * l * C_{0}$ : initial absorbance of the free ligand solution (no metal added).

$A_{\text {final }}=\varepsilon_{\text {complexe }} * l * C_{0}$ : final absorbance when all the ligands are bound to manganese.

$A_{288}=\frac{A_{0}}{C_{0}} * C_{L}+\frac{A_{\text {final }}}{C_{0}} * C_{\text {complexe }}$

$A_{288}=\frac{A_{0}}{C_{0}} *(1-X) C_{0}+\frac{A_{\text {final }}}{C_{0}} * X C_{0}$

$A_{288}=A_{0} *(1-X)+A_{\text {final }} * X$

$\frac{A_{288}-A_{0}}{A_{0}}=\frac{A_{\text {final }}-A_{0}}{A_{0}} * X$

In the latter equation, $\mathrm{X}$ was replaced by

$$
\underline{1+n_{\text {equiv. }}+\frac{1}{K_{\text {ass }} * C_{0}}-\sqrt{\left(1+n_{\text {equiv. }}+\frac{1}{K_{\text {ass }} * C_{0}}\right)^{2}-4 * n_{\text {equiv. }}}}
$$

To fit the curve, $\quad \frac{A_{288}-A_{0}}{A_{0}}$ was plotted versus $\mathrm{n}_{\text {equiv. }} \frac{A_{\text {final }}-A_{0}}{A_{0}}$ was a variable parameter, as well as $\mathrm{K}_{\text {ass. }}$.

$\mathrm{K}_{\text {ass }}$ of $1.88 \pm 0.8410^{7}$ and $1.75 \pm 0.7410^{6}$ were found for $\mathbf{1}$ and $\mathbf{2}$ respectively. These values lead to $\mathrm{K}_{\mathrm{d} \mathbf{1}}=9.00 \pm 4.0010^{-8}$ and $\mathrm{K}_{\mathrm{d} 2}=7.00 \pm 3.0010^{-7}$.

\section{Experiments on HT29-MD2 cells}

\section{Cell culture}

HT29-MD2 intestinal epithelial cells were used for all experiments. HT29 human colon adenocarcinoma were obtained from the European Collection of Authenticated Cell Cultures (ECACC, Wiltshire, UK) and stably transfected to over-express MD2 as previously described. ${ }^{8,}{ }^{9}$ Cells were cultured in DMEM supplemented with $10 \%$ of heat-inactivated FBS, and $0.1 \%$ of blasticidin $\left(10 \mu \mathrm{g} \cdot \mathrm{mL}^{-1}\right)$ at $37^{\circ} \mathrm{C}$ in a $5 \% \mathrm{CO}_{2} /$ air atmosphere. 


\section{Cytotoxicity assay}

Cytotoxicity of the tested compounds and controls, with and without LPS, was assessed using lactate dehydrogenase (LDH) release assay, by following the release of the cytosolic lactate dehydrogenase (LDH) into the supernatant, indicating membrane damages. Cytotoxicity was considered when LDH release was more than $10 \%$.

- Concentration of LDH in supernatant: $800 \mu \mathrm{L}$ of a pyruvate/NADH solution (see below) was added into a $1 \mathrm{~mL}$ plastic cuvette, as well as $200 \mu \mathrm{L}$ of supernatant, and the decrease in absorbance at $340 \mathrm{~nm}$ was immediately monitored for 1 minute. The slope is proportional to LDH concentration in supernatant.

- Concentration of LDH in cell lysate: $800 \mu \mathrm{L}$ of a pyruvate/NADH solution (see below) was added into a $1 \mathrm{~mL}$ plastic cuvette, as well as $190 \mu \mathrm{L}$ of $0.1 \mathrm{M}$ PBS and $10 \mu \mathrm{L}$ of cell lysate, and the decrease in absorbance at $340 \mathrm{~nm}$ was immediately measured for 1 minute. The slope is proportional to LDH concentration in cell lysate.

- The percentage of LDH released in the supernatant was calculated as follows:

$\% \mathrm{LDH}_{\text {released }}=\left(\right.$ Slope $\left._{\text {supernatant }} \times 200 \times 5\right) /\left(\right.$ Slope $_{\text {supernatant }} \times 200 \times 5+$ Slope $\left._{\text {lysate }} \times 10 \times 100\right) \times 100$

- Solution of pyruvate/NADH: $4.1 \mathrm{mg}$ of pyruvic acid $(0.62 \mathrm{mM})$, and $7.7 \mathrm{mg}$ of NADH $(0.18 \mathrm{mM})$ in $60 \mathrm{~mL}$ of 0.1 M PBS (pH 7.4).

\section{Distribution, and quantification experiments}

Quantification of Mn-complexes by EPR in cell lysates

EPR spectra were recorded on a Bruker Elexsys 500 spectrometer (Bruker, Wissembourg, France) operating at X-band (9.82 $\mathrm{GHz}$ ), and a SHQ high-sensitivity cavity, in a glass capillary tube: microwave power, $32 \mathrm{~mW}$; modulation frequency, 100 $\mathrm{kHz}$; modulation amplitude, $18 \mathrm{G}$; receiver gain, $60 \mathrm{~dB}$; time constant, $40.96 \mathrm{~ms}$; conversion time, $40.96 \mathrm{~ms}$; datapoints, 1024; field center, $3500 \mathrm{G}$; sweep width, $1000 \mathrm{G}$; sweep time, $41.94 \mathrm{~s}$; nine scans; room temperature $\left(21{ }^{\circ} \mathrm{C}\right)$. Data acquisition and processing were performed using Bruker Xepr software.

Cells were cultured in a $75 \mathrm{~cm}^{2}$ flask to reach $90 \%$ confluency. They were incubated with medium only, or tested compounds at the desired concentration for 6 hours, at $37{ }^{\circ} \mathrm{C}$. After a washing with $0.9 \% \mathrm{NaCl}$, a chaotropic shock was performed by washing the cells once with $1 \mathrm{M} \mathrm{NaCl}$ to remove charged species pontentially externally associated to the cells. Cells were washed twice with $0.9 \% \mathrm{NaCl}$. They were harvested by scraping and centrifuged at $4^{\circ} \mathrm{C}$ for $10 \mathrm{~min}$ at $900 \mathrm{rpm}$. The supernatant was removed, $100 \mu \mathrm{L}$ of MilliQ water was added and two freezing/thawing cycles in liquid nitrogen were performed. The protein content was determined for each sample. Cell lysates were acidified with $\mathrm{HClO}_{4}(10 \% \mathrm{v} / \mathrm{v}$ final concentration), which freed manganese(II) ion from coordination. ${ }^{10}$ A calibration curve was established using $\mathrm{MnCl}_{2}$ in water acidified with $10 \% \mathrm{v} / \mathrm{v} \mathrm{HClO}_{4}$, and quantification of the manganese-content was performed using the two first lines in the six-line $\mathrm{Mn}^{2+} \mathrm{X}$-band EPR spectrum and reported per milligram of proteins.

$\underline{\text { Calibration with } \mathrm{MnCl}_{2}} \underline{\text { in } 10 \% \mathrm{v} / \mathrm{v} \mathrm{HClO}} 4$ :

EPR spectra of $\mathrm{MnCl}_{2}$ at different concentration: 


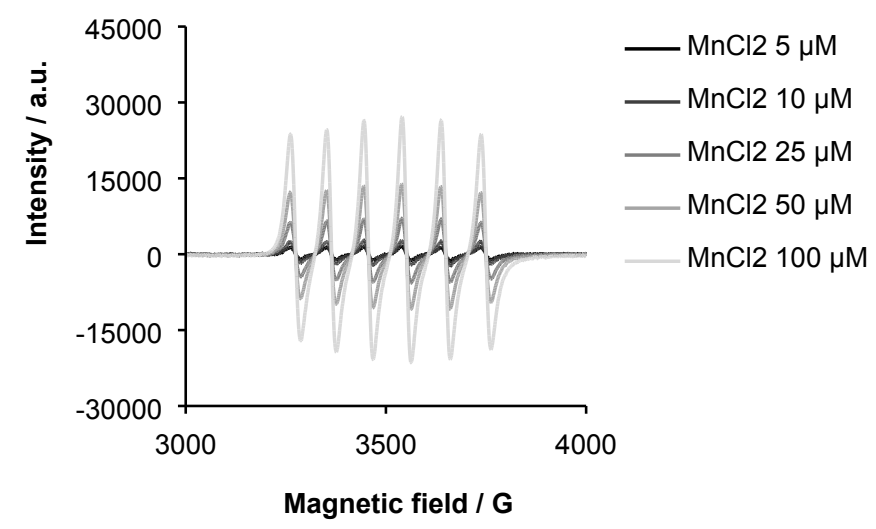

Plot of the two first lines height as a function of $\mathrm{MnCl}_{2}$ concentration, and linear fit:

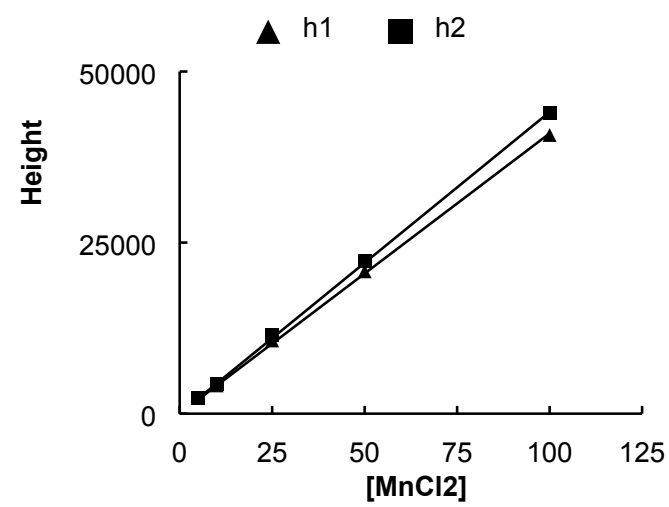

Determination of $\mathrm{Mn}$ total amount in samples after acidification with $\mathrm{HClO}_{4}$ :

EPR spectra of acidified cell lysate of cells incubated with $\underline{\mathbf{1}}, \underline{\mathbf{2}}$ or control cells $(\mathbf{T})$ :

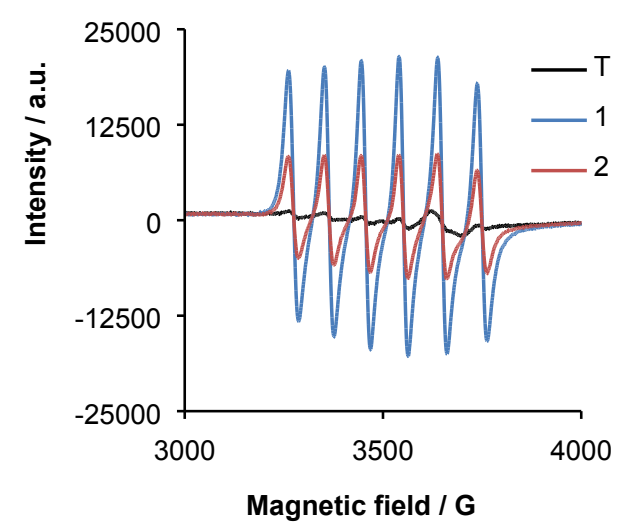

Quantification data obtained for $n=4$ experiments are listed in the table below. The heights of the two first lines were measured for each sample and are referred to as $h 1$ and $h 2$, respectively. The linear fit of the calibration curves determined with $\mathrm{MnCl}_{2}$ to correlate the signal height to the $\mathrm{Mn}$ concentration is then used to determine the concentration of $\mathrm{Mn}$ in each sample. Two values are obtained, $\mathrm{C}(\mathrm{h} 1)$ determined from $\mathrm{h} 1$, and $\mathrm{C}(\mathrm{h} 2)$ determined from $\mathrm{h} 2$, and are given in $\mu \mathrm{M}$. The average of this two values (C(average)) and the standard deviation are given in the Table. For some samples the average concentration was corrected by the dilution factor. The resulting concentration is referred to as $\mathrm{C}$ (dilution). Finally, ratio of the concentration of $\mathrm{Mn}$ in the sample (C(dilution)), and of the concentration of proteins in the sample (C(protein)), gives a concentration of $\mathrm{Mn}$ in the sample in nmol per mg of proteins. 
Calibration curve: linear fit: h1=335.45x; h2=359.67x

\begin{tabular}{|c|c|c|c|c|c|c|c|c|c|c|}
\hline & Samples & h1 & h2 & $\begin{array}{c}\mathbf{C}(\mathbf{h} 1) \\
\boldsymbol{\mu M} \\
\mathrm{h} 1 / 335.45 \\
\end{array}$ & $\begin{array}{c}\mathrm{C}(\mathrm{h} 2) \\
\mu \mathrm{M} \\
\mathrm{h} 2 / 359.67 \\
\end{array}$ & $\begin{array}{c}\mathbf{C}(\text { average) } \\
\mu \mathbf{M} \\
{[\mathrm{C}(\mathrm{h} 1)+\mathrm{C}(\mathrm{h} 2)] / 2}\end{array}$ & Std dev & $\begin{array}{c}\mathrm{C} \text { (dilution) } \\
\mu \mathrm{M}\end{array}$ & $\begin{array}{c}\mathrm{C} \text { (protein) } \\
\mu \mathrm{g} / \mu \mathrm{L}\end{array}$ & $\begin{array}{c}\text { Mn } \\
\text { nmol/mgprot } \\
\mathrm{C} \text { (dil.)/C(prot.) } \\
\end{array}$ \\
\hline \multirow[t]{3}{*}{ Replicate 1} & $\mathbf{T}$ & 392 & 370 & 1.17 & 1.03 & 1.10 & 0.10 & 1.28 & 2.14 & 0.60 \\
\hline & $\underline{2}$ & 5713 & 6231 & 17.03 & 17.32 & 17.18 & 0.21 & 20.04 & 6.54 & 3.06 \\
\hline & 1 & 2932 & 3171 & 8.74 & 8.82 & 8.78 & 0.05 & 10.24 & 2.66 & 3.85 \\
\hline \multirow[t]{3}{*}{ Replicate 2} & $\mathbf{T}$ & 354 & 364 & 1.06 & 1.01 & 1.03 & 0.03 & 1.21 & 3.42 & 0.35 \\
\hline & $\underline{2}$ & 2722 & 2910 & 8.11 & 8.09 & 8.10 & 0.02 & 9.45 & 5.15 & 1.84 \\
\hline & 1 & 8054 & 8559 & 24.01 & 23.80 & 23.90 & 0.15 & 27.89 & 3.99 & 6.98 \\
\hline
\end{tabular}

\section{Second set of samples}

Calibration curve: linear fit: h1= 410.07x; h2=441.39x

\begin{tabular}{|c|c|c|c|c|c|c|c|c|c|c|}
\hline & Samples & h1 & h2 & $\begin{array}{c}\mathbf{C}(\mathbf{h} 1) \\
\boldsymbol{\mu M} \\
\mathrm{h} 1 / 410.07 \\
\end{array}$ & $\begin{array}{c}\mathbf{C}(\mathbf{h} 2) \\
\boldsymbol{\mu M} \\
\mathrm{h} 2 / 441.39 \\
\end{array}$ & $\begin{array}{c}\mathrm{C} \text { (average) } \\
\mu \mathrm{M} \\
{[\mathrm{C}(\mathrm{h} 1)+\mathrm{C}(\mathrm{h} 2)] / 2}\end{array}$ & Std dev & $\begin{array}{c}\mathrm{C} \text { (dilution) } \\
\mu \mathrm{M}\end{array}$ & $\begin{array}{c}\text { Cprotein } \\
\mu g / \mu L\end{array}$ & $\begin{array}{c}\text { Mn } \\
\text { nmol/mgprot }\end{array}$ \\
\hline \multirow[t]{3}{*}{ Replicate 3} & $\underline{2}$ & 13000 & 14100 & 31.70 & 31.94 & 31.82 & 0.17 & 31.82 & 13.8 & 2.30 \\
\hline & 1 & 32580 & 34940 & 79.45 & 79.16 & 79.30 & 0.21 & 79.30 & 16.9 & 4.68 \\
\hline & $\mathbf{T}$ & 729 & 735 & 1.78 & 1.67 & 1.72 & 0.08 & 1.72 & 12.3 & 0.14 \\
\hline \multirow[t]{3}{*}{ Replicate 4} & $\underline{2}$ & 6120 & 6501 & 14.92 & 14.73 & 14.83 & 0.14 & 14.83 & 9.0 & 1.66 \\
\hline & 1 & 9390 & 10100 & 22.90 & 22.88 & 22.89 & 0.01 & 22.89 & 10.8 & 2.13 \\
\hline & $\mathrm{T}$ & 513 & 562 & 1.25 & 1.27 & 1.26 & 0.02 & 1.26 & 11.2 & 0.11 \\
\hline
\end{tabular}

\section{Comparison of EPR and ICP-MS method:}

Two replicate of compound $\underline{\mathbf{2}}$ were analyzed by EPR and ICP-MS to compare the values obtained by these two methods. As can be seen from the values and the figure below, the only difference between the two methods is the higher standard deviation in the case of EPR.

Mn content, nmol.mg-1 protein

\begin{tabular}{lrrrr} 
& Replicate 1 & Replicate 2 & \multicolumn{1}{l}{ Average } & standard deviation \\
\hline EPR & 3,85 & 6,98 & 5,42 & 2,21 \\
ICP-MS & 5,66 & 5,92 & 5,79 & 0,19 \\
\hline
\end{tabular}

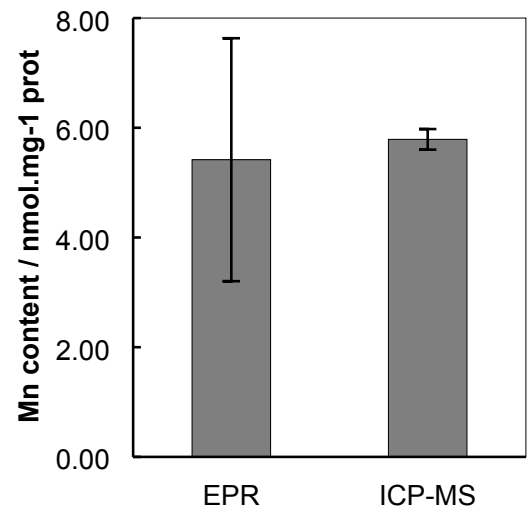


Cells were cultured in a $75 \mathrm{~cm}^{2}$ flask to reach $90 \%$ confluency. They were incubated with compounds at the desired concentration for 6 hours, at $37{ }^{\circ} \mathrm{C}$ (at $100 \mu \mathrm{M}$ for compound 1 in $2 \%$ DMSO for replicates $1-5$ and in $0.02 \%$ DMSO for replicates 6-7). After a washing with $0.9 \% \mathrm{NaCl}$, a chaotropic shock was performed by washing the cells once with $1 \mathrm{M}$ $\mathrm{NaCl}$ to remove charged species externally associated to the cells. Cells were washed twice with $0.9 \% \mathrm{NaCl}$. They were then harvested by scraping and centrifuged at $4{ }^{\circ} \mathrm{C}$ during $10 \mathrm{~min}$ at $800 \mathrm{rpm}$ (replicates 1-5) or $900 \mathrm{rpm}$ (replicates 6 and 7). The samples were diluted with $1 \mathrm{~mL}$ of milliQ water and protein content was determined for each sample using the Bradford assay.

Enriched mitochondria fraction was obtained as follows: cells were centrifuged at $4{ }^{\circ} \mathrm{C}$ during 5 min at $800 \mathrm{rpm}$, and the supernatant was removed. A Mitochondria Isolation Kit for cultured cells (Thermo Fisher Scientific, Waltham, Massachussetts, USA) was used, and three freezing/thawing cycles in liquid nitrogen were performed on isolated mitochondrial pellets.

Then, the samples were further diluted into $2 \% \mathrm{HNO}_{3}$ to obtain a final volume of $3 \mathrm{~mL}$ and were filtered $(0.2 \mu \mathrm{m})$. A calibration curve was established using a Mn standard for ICP-MS in $2 \% \mathrm{HNO}_{3}$ to quantify the amount of manganese into the fractions. The data are reported in pmol per $\mathrm{mg}$ of proteins.

Seven independent experiments (in different cell passage) were performed, and are referred to as Replicate 1-7. ICP-MS analysis for Replicate 1-2 was conducted on the same day, as well as Replicate 3-5, and Replicate 6-7. For Replicates 1-5 each condition was tested in duplicate, which is indicated by $a$, or $b$. In total, 12 samples were analyzed for each condition considering all replicates.

\section{REPLICATES 1 and 2}

\section{Calibration:}

A stock solution of $0.06685 \mathrm{ppm}$ of $\mathrm{Mn}$ in $2 \% \mathrm{HNO}_{3}$ was prepared from commercially available Mn standard for ICP-MS (1003 ppm) diluted in $2 \% \mathrm{HNO}_{3}$ solution. This stock solution was used to prepare the standards for the calibration curve, as listed in the Table below. For a given standard, the volume (in $\mu \mathrm{L}$ ) of stock solution was diluted with the specified final volume of $2 \% \mathrm{HNO}_{3}$ solution in the Table below. The theoretical Mn concentration is indicated in ppb.

The calibration curve obtained is shown in the Figure below, and the corresponding data are reported in the Table. The counts number for Mn (CPS Mn) represents the average of 3 measurements, and the standard deviation is given (CPS RSD). The concentration determined from the linear fit is referred to as Mn exp. and is given in ppb.

\section{Standards Preparation}

\begin{tabular}{|c|c|c|c|c|c|c|c|}
\hline Mn/Re vol $(\mu \mathrm{L})$ & 0 & 12.5 & 25 & 125 & 250 & 500 & 1000 \\
\hline Total vol (mL) & 25.00 & 25.00 & 25.00 & 25.00 & 25.00 & 25.00 & 25.00 \\
\hline Mn theo. (ppb) & 0 & 0.0334 & 0.0668 & 0.3342 & 0.6685 & 1.3370 & 2.6740 \\
\hline \multicolumn{8}{|c|}{ Measurement by ICP-MS } \\
\hline CPS Mn & 48 & 98 & 318 & 1916 & 3929 & 8114 & 16736 \\
\hline CPS RSD & 236 & 84 & 67 & 7 & 8 & 5 & 3 \\
\hline 55Mn exp. (ppb) & 0.008 & 0.016 & 0.051 & 0.309 & 0.634 & 1.309 & 2.700 \\
\hline
\end{tabular}




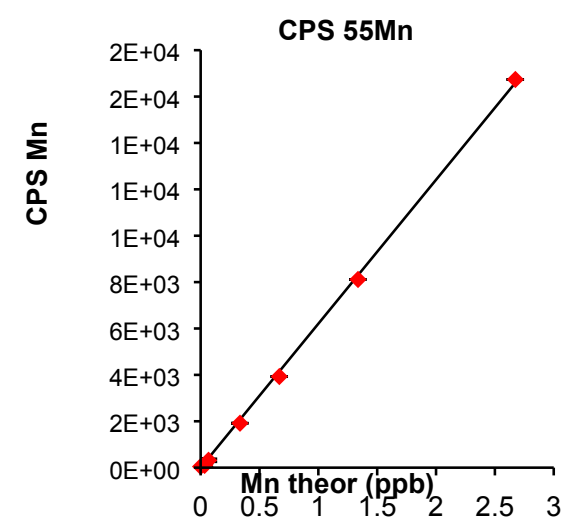

$\underline{\text { Determination of Mn total amount in mitochondria by ICP-MS }}$

The samples prepared were further diluted by mixing $1 \mathrm{~mL}$ of sample with $2 \mathrm{~mL}$ of $2 \% \mathrm{HNO}_{3}$. Each sample was measured in triplicate and counts value and standard deviation are listed in the table below. From, the calibration curve the Mn concentrations in ppb in the diluted samples were determined. Using the total mass of each sample (mtot sample), the amount of $\mathrm{Mn}$ in ng, and in nmol was determined. This corresponds to the total amount of Mn in the mitochondrial fraction. This amount can be reported vs. the protein content using the determined protein concentration of the saple (Cprot), and the initial volume of the sample $(1 \mathrm{~mL})$.

\begin{tabular}{|c|c|c|c|c|c|}
\hline & CPS & CPS Mn [He] & CPS RSD & & \\
\hline \multirow{9}{*}{$\begin{array}{l}\text { Mn counts } \\
\text { number for each } \\
\text { replicate }\end{array}$} & Replicate 1a $\underline{\mathbf{2}}$ mito & 3060.424 & 7.0985 & & \\
\hline & Replicate $1 \mathrm{~b} \underline{\mathbf{2}}$ mito & 4376.756 & 5.7212 & & \\
\hline & Replicate $2 \mathrm{a} \underline{\mathbf{2}}$ mito & 3480.512 & 10.1570 & & \\
\hline & Replicate $2 \mathrm{~b} \underline{\mathbf{2}}$ mito & 5427.114 & 4.0077 & & \\
\hline & Replicate $1 \mathrm{a} \underline{1}$ mito & 3210.454 & 4.2405 & & \\
\hline & Replicate $1 \mathrm{~b} \underline{1}$ mito & 3830.632 & 4.7702 & & \\
\hline & Replicate $2 a \underline{1}$ mito & 3564.552 & 6.8375 & & \\
\hline & Replicate $2 \mathrm{~b} \underline{1}$ mito & 3906.626 & 9.5004 & & \\
\hline & $\mathrm{ppb}(\mathrm{ng} / \mathrm{g})$ & Mn & err & mtot sample (g) & Dilution factor \\
\hline \multirow{9}{*}{$\begin{array}{l}\text { Conversion to } \\
\text { ppb using the } \\
\text { calibration curve }\end{array}$} & Replicate 1a $\underline{\mathbf{2}}$ mito & 0.493784 & 0.001145 & 3.0 & 3 \\
\hline & Replicate $1 \mathrm{~b} \underline{\mathbf{2}}$ mito & 0.706168 & 0.000923 & 3.0 & 3 \\
\hline & Replicate $2 \mathrm{a} \underline{\mathbf{2}}$ mito & 0.561563 & 0.001639 & 3.0 & 3 \\
\hline & Replicate $2 \mathrm{~b} \underline{\mathbf{2}}$ mito & 0.875638 & 0.000647 & 3.0 & 3 \\
\hline & Replicate $1 \mathrm{a} \underline{1}$ mito & 0.517991 & 0.000684 & 3.0 & 3.53 \\
\hline & Replicate $1 \mathrm{~b} \underline{1}$ mito & 0.618053 & 0.000770 & 3.0 & 3.53 \\
\hline & Replicate $2 \mathrm{a} \underline{1}$ mito & 0.575123 & 0.001103 & 3.0 & 3.53 \\
\hline & Replicate $2 \mathrm{~b} \underline{1}$ mito & 0.630314 & 0.001533 & 3.0 & 3.53 \\
\hline & $m(n g)$ & Mn & err & & \\
\hline $\begin{array}{l}\text { Determination of } \\
\text { the Mn mass in }\end{array}$ & Replicate 1a $\underline{\mathbf{2}}$ mito & 4.44406 & 0.01031 & & \\
\hline
\end{tabular}




\begin{tabular}{|c|c|c|c|c|c|}
\hline \multirow[t]{2}{*}{ each sample } & Replicate $1 \mathrm{~b} \underline{\mathbf{2}}$ mito & 6.35551 & 0.00831 & & \\
\hline & Replicate $2 \mathrm{a} \underline{\mathbf{2}}$ mito & 5.05407 & 0.01475 & & \\
\hline \multirow{9}{*}{$\begin{array}{l}\text { ppb * mtot sample } \\
{ }^{*} \text { Dilution factor }\end{array}$} & Replicate $2 \mathrm{~b} \underline{\mathbf{2}}$ mito & 7.88074 & 0.00582 & & \\
\hline & Replicate $1 \mathrm{a} \underline{1}$ mito & 5.48461 & 0.00724 & & \\
\hline & Replicate $1 \mathrm{~b} \underline{1}$ mito & 6.54409 & 0.00815 & & \\
\hline & Replicate $2 \mathrm{a} 1$ mito & 6.08953 & 0.01168 & & \\
\hline & Replicate $2 \mathrm{~b} 1$ mito & 6.67392 & 0.01623 & & \\
\hline & n (nmol) & Mn & err & Cprot (mg/mL) & $V(m L)$ \\
\hline & Replicate 1a $\underline{2}$ mito & 0.08089 & 0.00019 & 0.93 & 1 \\
\hline & Replicate $1 \mathrm{~b} \underline{\mathbf{2}}$ mito & 0.11569 & 0.00015 & 0.81 & 1 \\
\hline & Replicate $2 \mathrm{a} \underline{\mathbf{2}}$ mito & 0.09200 & 0.00027 & 0.55 & 1 \\
\hline \multirow{7}{*}{$\begin{array}{l}\text { Conversion to } \\
\text { mole }\end{array}$} & Replicate $2 \mathrm{~b} \underline{\mathbf{2}}$ mito & 0.14345 & 0.00011 & 0.54 & 1 \\
\hline & Replicate $1 \mathrm{a} \underline{1}$ mito & 0.09983 & 0.00013 & 0.86 & 1 \\
\hline & Replicate $1 \mathrm{~b} \underline{1}$ mito & 0.11912 & 0.00015 & 0.88 & 1 \\
\hline & Replicate $2 \mathrm{a} 1$ mito & 0.11084 & 0.00021 & 0.54 & 1 \\
\hline & Replicate $2 \mathrm{~b} \underline{1}$ mito & 0.12148 & 0.00030 & 0.76 & 1 \\
\hline & C (pmol/mg prot) & Mn & err & & \\
\hline & Replicate 1a $\underline{\mathbf{2}}$ mito & 87.0593 & 0.2019 & & \\
\hline \multirow{4}{*}{$\begin{array}{l}\text { Determination of } \\
\text { the Mn } \\
\text { concentration } \\
\text { reported vs. } \\
\text { protein content }\end{array}$} & Replicate $1 \mathrm{~b} \underline{\mathbf{2}}$ mito & 142.5940 & 0.1864 & & \\
\hline & Replicate 2a $\underline{2}$ mito & 166.7727 & 0.4867 & & \\
\hline & Replicate $2 \mathrm{~b} \underline{\mathbf{2}}$ mito & 265.3836 & 0.1960 & & \\
\hline & Replicate $1 \mathrm{a} \underline{1}$ mito & 116.4838 & 0.1539 & & \\
\hline \multirow{5}{*}{$\begin{array}{l}n \text { *1000 / (Cprot * } \\
\text { V) }\end{array}$} & Replicate $1 \mathrm{~b} \underline{1}$ mito & 136.0145 & 0.1694 & & \\
\hline & Replicate $2 \mathrm{a} 1$ mito & 206.7890 & 0.3967 & & \\
\hline & Replicate $2 \mathrm{~b} \underline{1}$ mito & 160.653 & 0.1318 & & \\
\hline & & Mn & stdev & & \\
\hline & Replicate $1 \underline{2}$ mito & 114.83 & 39.27 & & \\
\hline \multirow{3}{*}{$\begin{array}{l}\text { Average for } \\
\text { each replicate }\end{array}$} & Replicate $2 \underline{\mathbf{2}}$ mito & 216.08 & 69.73 & & \\
\hline & Replicate 11 mito & 126.25 & 13.81 & & \\
\hline & Replicate 21 mito & 183.72 & 45.67 & & \\
\hline
\end{tabular}

\section{REPLICATES 3-5}

Calibration: 
A stock solution of $0.06685 \mathrm{ppm}$ of $\mathrm{Mn}$ in $2 \% \mathrm{HNO}_{3}$ was prepared from commercially available Mn standard for ICP-MS (1003 ppm) diluted in $2 \% \mathrm{HNO}_{3}$ solution. This stock solution was used to prepare the standards for the calibration curve, as listed in the Table below. For a given standard, the volume (in $\mu \mathrm{L}$ ) of stock solution was diluted with the specified final volume of $2 \% \mathrm{HNO}_{3}$ solution in the Table below. The theoretical Mn concentration is indicated in ppb.

The calibration curve obtained is shown in the Figure below, and the corresponding data are reported in the Table. The counts number for Mn (CPS Mn) represents the average of 3 measurements, and the standard deviation is given (CPS RSD). The concentration determined from the linear fit is referred to as Mn exp. and is given in ppb.

\begin{tabular}{|c|c|c|c|c|c|c|c|c|}
\hline \multicolumn{9}{|c|}{ Standards Preparation } \\
\hline Mn vol $(\mu \mathrm{L})$ & 0 & 12.5 & 25 & 125 & 250 & 500 & 1000 & 1250 \\
\hline Total vol (mL) & 25.00 & 25.00 & 25.00 & 25.00 & 25.00 & 25.00 & 25.00 & 25.00 \\
\hline Mn theo. (ppb) & 0 & 0.0334 & 0.0669 & 0.3343 & 0.6687 & 1.3373 & 2.6747 & 3.3433 \\
\hline \multicolumn{9}{|c|}{ Measurement by ICP-MS } \\
\hline CPS Mn & 52 & -373 & -54 & 2388 & 5423 & 11165 & 23016 & 28508 \\
\hline CPS RSD & 61 & -6 & -65 & 4 & 1 & 2 & 1 & 1 \\
\hline 55Mn exp. (ppb) & 0.0061 & -0.0437 & -0.0063 & 0.2803 & 0.6365 & 1.3106 & 2.7018 & 3.3464 \\
\hline
\end{tabular}

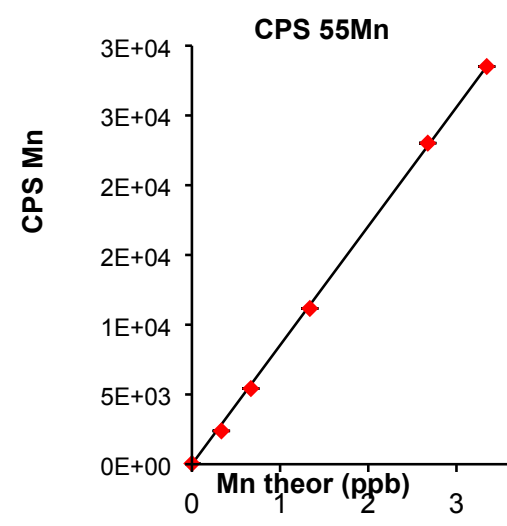

Determination of Mn total amount in mitochondria by ICP-MS

The samples prepared were further diluted by mixing $1 \mathrm{~mL}$ of sample with $2 \mathrm{~mL}$ of $2 \% \mathrm{HNO}_{3}$. Each sample was measured in triplicate and counts value and standard deviation are listed in the table below. From, the calibration curve the Mn concentrations in ppb in the diluted samples were determined. Using the total mass of each sample (mtot sample), the amount of $\mathrm{Mn}$ in $\mathrm{ng}$, and in nmol was determined. This corresponds to the total amount of $\mathrm{Mn}$ in the mitochondrial fraction. This amount can be reported vs. the protein content using the determined protein concentration of the saple (Cprot), and the initial volume of the sample $(1 \mathrm{~mL})$.

\begin{tabular}{llll}
\hline & CPS & CPS Mn [He] & CPS RSD \\
& Replicate 3a $\underline{\mathbf{2}}$ mito & 11434.84 & 2.601656124 \\
& Replicate 3b $\underline{\mathbf{2}}$ mito & 18601.08 & 0.653053583 \\
& Replicate 4a $\underline{\mathbf{2}}$ mito & 13736.552 & 0.92291733 \\
& Replicate 4b $\underline{\mathbf{2}}$ mito & - & - \\
$\begin{array}{l}\text { Mn } \quad \text { counts } \\
\text { number for each }\end{array}$ & Replicate 5a $\underline{\mathbf{2}}$ mito & 11990.894 & 1.406861767 \\
& Replicate 5b $\underline{\mathbf{2}}$ mito & 22182.868 & 0.6509659 \\
& Replicate 3a $\underline{\mathbf{1}}$ mito & 17017.528 & 1.656177599 \\
& Replicate 3b $\underline{\mathbf{1}}$ mito & 24613.968 & 0.559436779 \\
& Replicate 4a $\underline{\mathbf{1}}$ mito & 16990.918 & 1.190079979 \\
& Replicate 4b $\underline{\mathbf{1}}$ mito & 17974.866 & 0.9895 \\
\hline
\end{tabular}




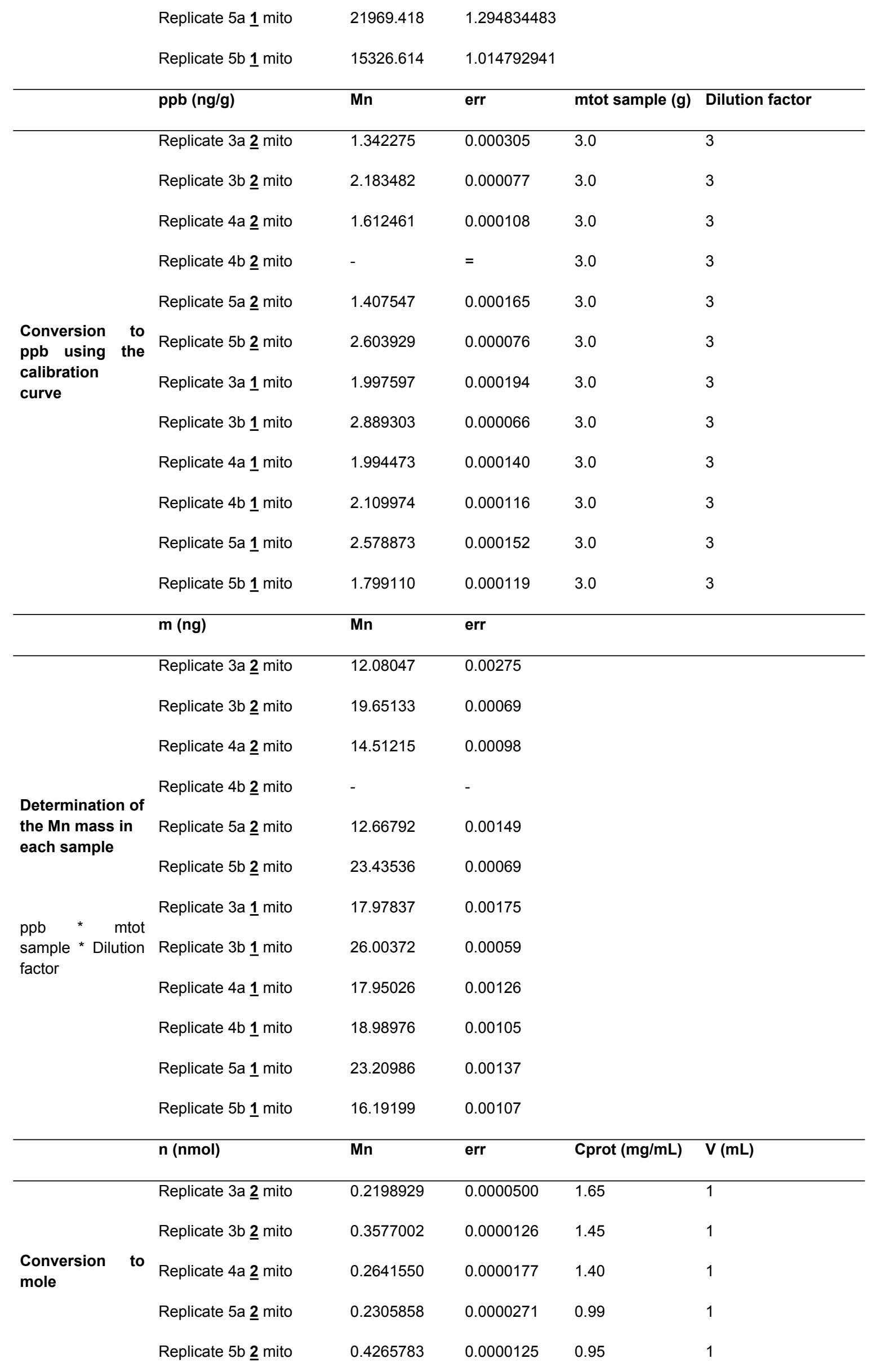




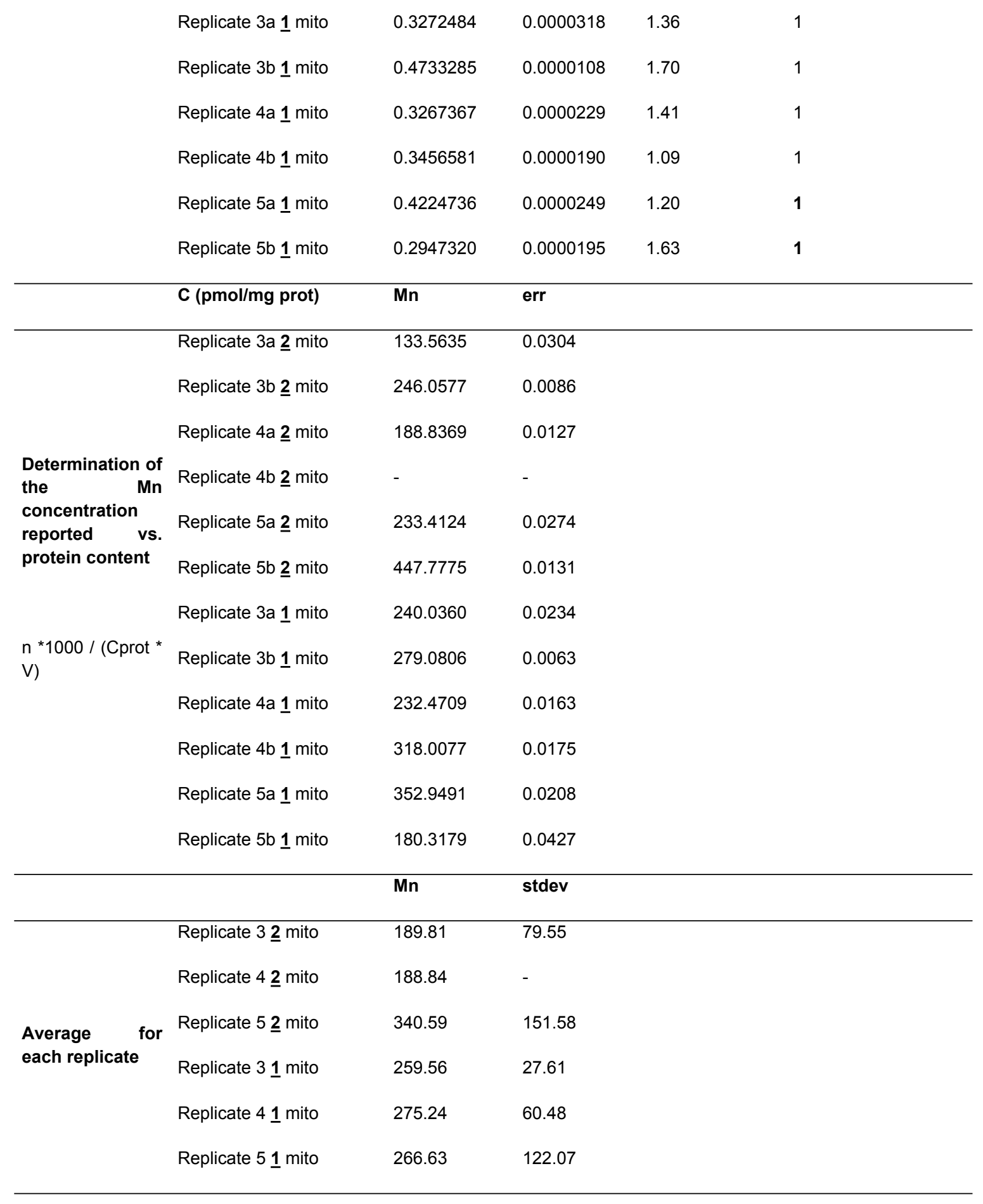

\section{REPLICATES 6 and 7}

\section{Calibration:}

A stock solution of $0.221 \mathrm{ppm}$ of $\mathrm{Mn}$ in $2 \% \mathrm{HNO}_{3}$ was prepared by weighting $2 \mathrm{mg}$ of commercially available Mn standard for ICP-MS (1003 ppm) and diluting it with $2 \% \mathrm{HNO}_{3}$ solution to a final mass of $9998.3 \mathrm{mg}$. This stock solution was used to prepare the standards for the calibration curve, as listed in the Table below. For a given standard, the mass $m$ of stock solution was diluted with $2 \% \mathrm{HNO}_{3}$ solution to the specified final mass, referred to as standard mass in the Table below. The theoretical Mn concentration is indicated in ppb. 
The calibration curve obtained is shown in the Figure below, and the corresponding data are reported in the Table. The counts number for Mn (CPS Mn) represents the average of 3 measurements, and the standard deviation is given (CPS RSD). The concentration determined from the linear fit is referred to as Mn exp. and is given in ppb.

\begin{tabular}{|c|c|c|c|c|c|c|c|}
\hline \multicolumn{8}{|c|}{ Standards Preparation } \\
\hline$M n(\mathrm{mg})$ & 0 & 10.4 & 50.5 & 101.5 & 499.1 & 1014.2 & 5031.7 \\
\hline Total mass $(\mathrm{g})$ & 25 & 25.0036 & 25.0944 & 25.0166 & 24.9993 & 25.003 & 24.9797 \\
\hline Mn theo. (ppb) & 0 & 0.092 & 0.444 & 0.895 & 4.406 & 8.952 & 44.455 \\
\hline \multicolumn{8}{|c|}{ Measurement by ICP-MS } \\
\hline CPS Mn & 35 & 669 & 3855 & 7850 & 38152 & 75839 & 375664 \\
\hline CPS RSD & 164 & 7 & 4 & 3 & 1 & 1 & 1 \\
\hline Mn exp. (ppb) & 0.004 & 0.079 & 0.456 & 0.929 & 4.513 & 8.972 & 44.440 \\
\hline
\end{tabular}

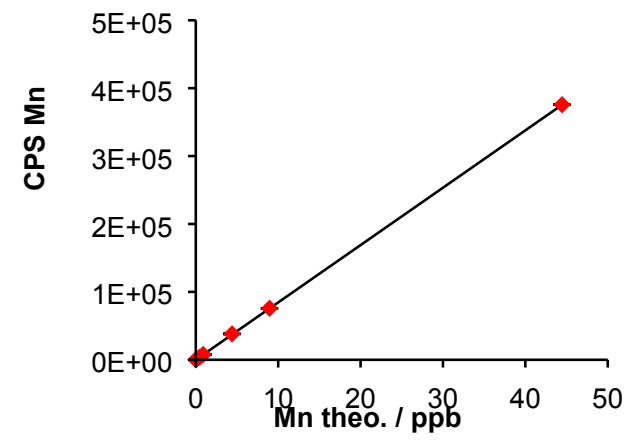

Determination of Mn total amount in mitochondria by ICP-MS:

Each sample was measured in triplicate and counts value and standard deviation are listed in the table below. From, the calibration curve the Mn concentrations in ppb in the diluted samples were determined. Using the total mass of each sample (mtot sample), the amount of $\mathrm{Mn}$ in $\mathrm{ng}$, and in nmol was determined. This corresponds to the total amount of $\mathrm{Mn}$ in the mitochondrial fraction. This amount can be reported vs. the protein content using the determined protein concentration of the saple (Cprot), and the initial volume of the sample $(1 \mathrm{~mL})$.

\begin{tabular}{|c|c|c|c|c|}
\hline & CPS & CPS Mn & CPS RSD & \\
\hline \multirow{5}{*}{$\begin{array}{l}\text { Mn counts number for each } \\
\text { replicate }\end{array}$} & Replicate $6 \underline{\mathbf{2}}$ mito & 16665 & 1 & \\
\hline & Replicate $7 \underline{\mathbf{2}}$ mito & 10267 & 1 & \\
\hline & Replicate 61 mito & 24642 & 0 & \\
\hline & Replicate 71 mito & 8333 & 2 & \\
\hline & $\mathrm{ppb}(\mathrm{ng} / \mathrm{g})$ & Mn & err & mtot sample (g) \\
\hline \multirow{5}{*}{$\begin{array}{l}\text { Conversion to ppb using the } \\
\text { calibration curve }\end{array}$} & Replicate $6 \underline{\mathbf{2}}$ mito & 1.971 & $2 \mathrm{E}-04$ & 3.0072 \\
\hline & Replicate $7 \underline{2}$ mito & 1.215 & $1 \mathrm{E}-04$ & 3.1491 \\
\hline & Replicate 61 mito & 2.915 & $5 \mathrm{E}-05$ & 3.0053 \\
\hline & Replicate 71 mito & 0.986 & $2 \mathrm{E}-04$ & 3.0078 \\
\hline & m (ng) & Mn & err & \\
\hline \multirow{5}{*}{$\begin{array}{l}\text { Determination of the Mn mass in } \\
\text { each sample }\end{array}$} & Replicate $6 \underline{\mathbf{2}}$ mito & 5.928 & $5 \mathrm{E}-04$ & \\
\hline & Replicate $7 \underline{\mathbf{2}}$ mito & 3.825 & $4 \mathrm{E}-04$ & \\
\hline & Replicate $6 \underline{1}$ mito & 8.761 & $1 \mathrm{E}-04$ & \\
\hline & Replicate 71 mito & 2.965 & 7E-04 & \\
\hline & n (nmol) & Mn & err & Cprot $(\mathrm{mg} / \mathrm{mL}) \quad$ V (mL) \\
\hline Conversion to mole & Replicate $6 \underline{\mathbf{2}}$ mito & 0.108 & $9 \mathrm{E}-06$ & 1.85 \\
\hline
\end{tabular}




\begin{tabular}{|c|c|c|c|c|c|}
\hline & Replicate $7 \underline{\mathbf{2}}$ mito & 0.070 & 7E-06 & 2.21 & 1.0 \\
\hline & Replicate 61 mito & 0.159 & $3 E-06$ & 1.78 & 1.0 \\
\hline & Replicate 71 mito & 0.054 & $1 \mathrm{E}-05$ & 1.64 & 1.0 \\
\hline & C (pmol/mg prot) & Mn & err & & \\
\hline \multirow{2}{*}{$\begin{array}{c}\text { Determination of the Mn } \\
\text { concentration reported vs. protein } \\
\text { content }\end{array}$} & Replicate $6 \underline{\mathbf{2}}$ mito & 56.79 & $5 \mathrm{E}-03$ & & \\
\hline & Replicate $\mathbf{7} \underline{\mathbf{2}}$ mito & 31.64 & $3 E-03$ & & \\
\hline \multirow{2}{*}{$n$ *1000 / (Cprot *V) } & Replicate 61 mito & 88.59 & $1 \mathrm{E}-03$ & & \\
\hline & Replicate 71 mito & 33.73 & 7E-03 & & \\
\hline
\end{tabular}

\section{SUMMARY FOR REPLICATES 1-7}

\begin{tabular}{|c|c|c|c|c|}
\hline & \multirow{2}{*}{$\begin{array}{l}\text { Mn } \\
114.83\end{array}$} & \multirow{2}{*}{$\begin{array}{l}\text { stdev } \\
39.27\end{array}$} & \multirow{2}{*}{$\begin{array}{c}\text { Mn } \pm \text { SEM } \\
162 \pm 40\end{array}$} \\
\hline & Replicate $1 \underline{\mathbf{2}}$ mito & & & \\
\hline & Replicate $2 \underline{\mathbf{2}}$ mito & 216.08 & 69.73 & \\
\hline & Replicate $3 \underline{\mathbf{2}}$ mito & 189.81 & 79.55 & \\
\hline & Replicate $4 \underline{\mathbf{2}}$ mito & 188.84 & - & \\
\hline & Replicate $5 \underline{\mathbf{2}}$ mito & 340.59 & 151.58 & \\
\hline & Replicate $6 \underline{\mathbf{2}}$ mito & 56.79 & - & \\
\hline $\begin{array}{l}\text { Average for each } \\
\text { replicate }\end{array}$ & Replicate $7 \underline{\mathbf{2}}$ mito & 31.64 & - & \\
\hline \multirow[t]{7}{*}{ pmol/mg prot } & - Réplicate $\overline{1} 1 \overline{\text { mito }}$ & $\overline{126.25}$ & $\overline{13.8 \overline{1}}$ & $\overline{176} \pm \overline{3} 6-----$ \\
\hline & Replicate $2 \underline{1}$ mito & 183.72 & 45.67 & \\
\hline & Replicate $3 \underline{1}$ mito & 259.56 & 27.61 & \\
\hline & Replicate $4 \underline{1}$ mito & 275.24 & 60.48 & \\
\hline & Replicate $5 \underline{1}$ mito & 266.63 & 122.07 & \\
\hline & Replicate $6 \underline{1}$ mito & 88.59 & - & \\
\hline & Replicate $7 \underline{1}$ mito & 33.73 & - & \\
\hline
\end{tabular}

\section{Infra-red (IR) imaging of $\underline{\mathbf{1}}$}

HT29-MD2 cells were seeded on silicon nitride windows (size: $5 \mathrm{~mm}$ x $5 \mathrm{~mm}$, thickness: $500 \mathrm{~nm}$ ) in 24-wells plate (75 000 cells/well). After $24 \mathrm{~h}$, cells were incubated with $\underline{\mathbf{1}}(100 \mu \mathrm{M}, 0.02 \% \mathrm{DMSO})$ for $2 \mathrm{~h}$ at $37^{\circ} \mathrm{C}$. Cells were washed with $0.9 \%$ $\mathrm{NaCl}$ and a chaotropic shock was performed by washing the cells once with $1 \mathrm{M} \mathrm{NaCl}$. They were then washed once with EDTA $(50 \mathrm{mM})$, and twice with $0.9 \% \mathrm{NaCl}$. Cells were cryofixed in liquid ethane and freeze-dried. FTIR-SM images were taken with a $15 \mathrm{X}$ magnification 0.62 numerical aperture objective giving a field of view of $350 \times 350 \mu \mathrm{m}^{2}$ and a projected pixel size of $5.5 \times 5.5 \mu \mathrm{m}^{2}$ at standard magnification. The microscope was coupled to a Cary 660 spectrometer equipped with a $\mathrm{KBr}$ beamsplitter and a Michelson interferometer. Spectra were recorded at $8 \mathrm{~cm}^{-1}$ resolution between 800 and $4000 \mathrm{~cm}^{-}$ ${ }^{1}$ with 256 co-added scans at $2.5 \mathrm{~Hz}$ mirror speed.

Fourier transform infrared spectromicroscopy (FTIR-SM) study of cryofixed and freeze-dried HT29-MD2 cells incubated with $\underline{\mathbf{1}}$ was performed to detect the coordinated carbonyl moiety of $\underline{\mathbf{1}}$ (Fig. S9). The A1 and E bands specific of the carbonyl moieties can be used to detect the complex, ${ }^{11-14}$ which was successfully identified in cells, whereas no band was detected in control cells. The spatial resolution of this microscope is too low to determine a subcellular location of $\underline{\mathbf{1}}$, however the 
mapping of the A1-band integrated between $2055-2005 \mathrm{~cm}^{-1}$ and the IR spectrum clearly show that cells incubated with $\underline{\mathbf{1}}$ contain a $\operatorname{Re}(\mathrm{CO})_{3}$ moiety.

Synchrotron radiation X-ray fluorescence microscopy

- APS synchrotron:

HT29-MD2 cells were seeded on silicon nitride windows (size: $5 \mathrm{~mm}$ x $5 \mathrm{~mm}$, thickness: $500 \mathrm{~nm}$ ) in 24-wells plate (75 000 cells/well). After $24 \mathrm{~h}$, cells were incubated with $\underline{\mathbf{1}}(100 \mu \mathrm{M}, 0.02 \% \mathrm{DMSO})$ for $2 \mathrm{~h}$ at $37{ }^{\circ} \mathrm{C}$. Cells were washed with $0.9 \%$ $\mathrm{NaCl}$ and a chaotropic shock was performed by washing the cells once with $1 \mathrm{M} \mathrm{NaCl}$. They were then washed once with EDTA $(50 \mathrm{mM})$ when specified, and twice with $0.9 \% \mathrm{NaCl}$. Cells were cryofixed in liquid ethane and freeze-dried.

Mappings of intracellular manganese $(\mathrm{Mn})$, potassium $(\mathrm{K})$, phosphate $(\mathrm{P})$, sulfur $(\mathrm{S})$, zinc $(\mathrm{Zn})$, iron $(\mathrm{Fe})$, and rhenium $(\mathrm{Re})$ were performed on the 2-ID-D beamline of Advanced Photon Source synchrotron (Argonne National Laboratory, Chicago, USA). Cells were located using a phase-contrast optical microscope. All measurements were conducted at room temperature. Excitation, $12.0 \mathrm{keV}$; integration time, $2 \mathrm{~s} \mathrm{pixel}^{-1}$; pixel size, $200 \mathrm{~nm}$.

Since the $\mathrm{Zn} \mathrm{K-} \alpha$ lines overlap with the Re L- $\alpha$ lines, spectral fitting was used to separate the XRF signal from the two elements. All the $\mathrm{Zn}$ K-lines (K- $\alpha, \mathrm{K}-\boldsymbol{\beta})$ and the Re L-lines (L- $\alpha, \mathrm{L}-\beta \mathrm{L}-\gamma, \mathrm{L} \lambda, \mathrm{L} v)$, together with their known branching ratios, were included in the fitting in order to better constrain the result. The elemental maps were calibrated using standards for each element, apart Re. For the latter, no standard is available, the concentration may thus vary by $\pm 50 \%$. Quantification of element concentration per cell was performed with Image $\mathrm{J}$ software. ${ }^{15,}{ }^{16}$ For each cell a cell mask was determined using the sum of P and S maps. The sum of pixel intensities $\left(\mu \mathrm{g} . \mathrm{cm}^{-2}\right)$ in the cell mask for a given element gave its concentration $\left(\mu \mathrm{g} \cdot \mathrm{cm}^{-2}\right)$.

- SOLEIL synchrotron:

HT29-MD2 cells were seeded on silicon nitride windows (size: $5 \mathrm{~mm}$ x $5 \mathrm{~mm}$, thickness: $500 \mathrm{~nm}$ ) in 24-wells plate (75 000 cells/well). After $24 \mathrm{~h}$, cells were incubated with $\underline{\mathbf{1}}(100 \mu \mathrm{M}, 0.02 \% \mathrm{DMSO})$ for $2 \mathrm{~h}$ at $37^{\circ} \mathrm{C}$. Mitotracker ${ }^{\mathrm{TM}}$ deep red $(200$ $\mathrm{nM}$ ) was added 30 minutes before the end of the incubation. Cells were washed with $0.9 \% \mathrm{NaCl}$ and a chaotropic shock was performed by washing the cells once with $1 \mathrm{M} \mathrm{NaCl}$ They were then washed once with EDTA $(50 \mathrm{mM})$, and twice with $0.9 \% \mathrm{NaCl}$. Cells were cryofixed in liquid ethane and freeze-dried.

Confocal fluorescence images of Mitotracker ${ }^{\mathrm{TM}}$ deep red (ex $633 \mathrm{~nm}$, em 645-750 nm) were recorded with open pinhole.

Mappings of intracellular manganese (Mn), potassium (K), phosphate (P), iron (Fe), and rhenium $(\mathrm{Re})$ were performed on the Nanoscopium beamline, ${ }^{17}$ of SOLEIL synchrotron (L'Orme des Merisiers Saint-Aubin, France). Cells were located using the optical microscope of the experimental station. In order to tailor the experimental conditions to the required high analytical sensitivity, the experiments were performed in the high flux operation mode of the beamline with $\sim 10^{10}$ photons $/ \mathrm{s}$ in the focused beam. The X-ray beam was focused by a Kirckpatrick-Baez nano-focusing mirror to $0.3 \times 0.3 \mu \mathrm{m}^{2}$ size at the sample position. For the maps the FLYSCAN continuous scanning mode was used with $300 \mathrm{~nm}$ image pixel-size. ${ }^{18}$ The full XRF spectra were collected in each pixel by two Si-drift detectors (VITUS H50, KETEK GmbH) in order to increase the solid angle of detection. The XRF spectra of the two detectors were added and the sum was used for calculating the elemental maps. After generating the elemental maps, for a given element the pixel intensities were normalized to the maximum pixel intensity value of the map, and converted to 16 bits images using the software Octave. ${ }^{19}$ As an example, the formula used to normalized the Fe map for a given cell and convert it to 16 bits image was:

$\mathrm{Fe}=\operatorname{uint} 16\left(\mathrm{Fe} / \max (\mathrm{Fe}(:)) * 2^{\wedge} 16\right) ;$ 


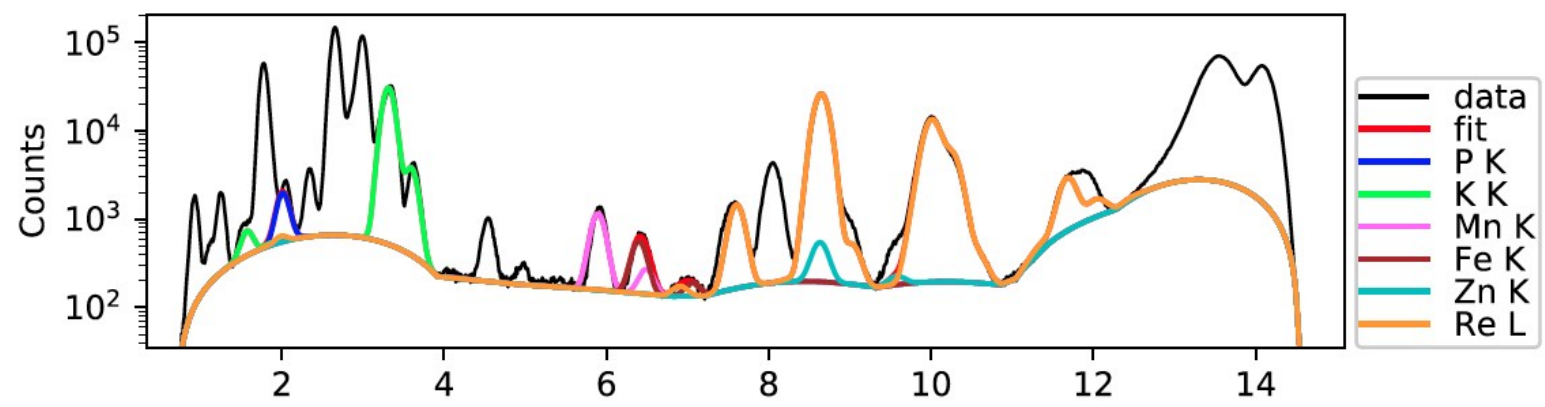

Mean spectrum of Figure S11 showing the deconvolution for the emission of P, K, Mn, Fe, Zn and Re, and the fit.

The $\mathrm{Zn}-\mathrm{K} \alpha$ and Re-L $\alpha(\sim 8.6 \mathrm{keV})$ lines are overlapping. However, the good energy resolution of the XRF detectors of the Nanoscopium beamline ensures the unambiguous deconvolution of the Re-L $\beta$ lines $(\sim 10.15$ and $10.28 \mathrm{keV})$. In order to avoid the eventual $\mathrm{Zn}$ and $\mathrm{Re}$ signal overlapping in the Re images, we used only the Re-L $\beta$ lines for creating the X-ray intensity maps.

All measurements were performed at room temperature with the experimental conditions of: monochromatic excitation energy14.1 keV (1) , or $9.9 \mathrm{keV}$ (control cells); integration time, $2.4 \mathrm{~s}^{\text {pixel }}{ }^{-1}$; pixel size, $300 \mathrm{~nm}$.

\section{Evaluation of the biological activity of $\mathrm{Mn}^{2+}$-complexes}

\section{Cell activation with LPS and incubation with the compounds}

HT29-MD2 cells were seeded in 24 well-plates at 200000 cells/well to reach $90 \%$ confluence after 3 or 4 days. Cells were incubated with media only, or the tested compounds at the desired concentration for $1 \mathrm{~h}$. Then, LPS was added $(0.1 \mu \mathrm{g} / \mathrm{mL}, 6$ hours). Supernatants were collected and stored at $-20{ }^{\circ} \mathrm{C}$ before ELISA and LDH assay. Cells were washed with $0.9 \% \mathrm{NaCl}$, lysed in PBS containing 1\% triton X-100 and protease inhibitors cocktail. They were harvested by scraping, and stored at -20 ${ }^{\circ} \mathrm{C}$ before western blot, cytotoxicity and protein quantification experiments

\section{Proteins concentration in cell lysate}

Protein concentrations were determined in cell lysates using bicinchoninic acid (BCA) protein assay reagents and bovine serum albumin (BSA) as standard according to the manufacturer's instructions.

\section{COX2 and SODs analysis}

Automated western blotting was performed on a WES automate (ProteinSimple, San Jose, CA) using a commercially available Wes 12-230 kDa Rabbit Master Kit (PS-MK01) and according to the instruction of the manufacturer. Samples of 5 $\mu \mathrm{L}$ were prepared from cell lysate using a master mix kit (ProteinSimple) to obtain a final concentration of protein of 0.4 $\mathrm{mg} / \mathrm{mL}$. Proteins were separated by molecular weight by capillary eletrophoresis. COX2, MnSOD and actin were detected using a solution containing the three primary antibodies (COX2 d 1:50, Sigma, SAB4200576; MnSOD d 1:25, SantaCruz Biotechnology, SC-30080; Actine d 1:1000, NOVUS, NB600-532), followed by a goat anti-rabbit HRP-conjugated secondary antibody (anti-rabbit) and a chemiluminescent substrate. Compass software (ProteinSimple) was used to analyze the data. The relative amount of each protein was calculated based on peak area and normalized to actin.

\section{IL8 quantification}

Levels of the pro-inflammatory cytokine IL8 produced by cells were determined in cell supernatants using a commercially available ELISA kit according to the instructions of the manufacturer. IL8 levels were normalized by the protein content determined in the corresponding cell lysates.

\section{Statistical analysis}


All data are represented as mean \pm SEM of $\mathrm{n}$ independent experiments and were tested for statistical significance using the Student's $t$ test. Differences were considered significant when $\mathrm{p}<0.05$

\section{Supplementary Information References}

1. J. M. McCord and I. Fridovich, J. Biol. Chem., 1969, 244, 6049-6055.

2. S. Durot, C. Policar, F. Cisnetti, F. Lambert, J.-P. Renault, G. Pelosi, G. Blain, H. Korri-Youssoufi and J.-P. Mahy, Eur. J. Inorg. Chem., 2005, 3513-3523.

3. C. Policar, in Redox Active Therapeutics, eds. J. S. Reboucas, I. Batinic-Haberle, I. Spasojevic, D. S. Warner and D. St. Clair, Springer, 2016, ch. Chapter 17, pp. 125-164.

4. H. Y. V. Ching, I. Kenkel, N. Delsuc, E. Mathieu, I. Ivanović-Burmazović and C. Policar, J. Inorg. Biochem., 2016, 160, 172-179.

5. F. C. Friedel, D. Lieb and I. Ivanovic-Burmazovic, J. Inorg. Biochem., 2012, 109, 26-32.

6. B. Halliwell and J. M. C. Gutteridge, Free radicals in biology and medicine Oxford University Press, New York 2007.

7. F. Cisnetti, A. S. Lefevre, R. Guillot, F. Lambert, G. Blain, E. Anxolabéhère-Mallart and C. Policar, Eur. J. Inorg. Chem., 2007, 4472-4480.

8. C. Lenoir, C. Sapin, A. H. Broquet, A.-M. Jouniaux, S. Bardin, I. Gasnereau, G. Thomas, P. Seksik, G. Trugnan, J. Masliah and M. Bachelet, Life Sci., 2008, 82, 519-528.

9. P. Seksik, H. Sokol, V. Grondin, C. Adrie, H. Duboc, B. Pigneur, G. Thomas, L. Beaugerie, G. Trugnan, J. Masliah and M. Bachelet, Innate Imunnity, 2010, 16, 381-390.

10. D. E. Ash and V. L. Schramm, J. Biol. Chem., 1982, 257, 9261-9264.

11. M. Salmain, A. Vessieres, G. Jaouen and I. S. Butler, Anal. Chem., 1991, 63, 2323-2329.

12. G. R. Stephenson, in Bioorganometallics-Biomolecules, labeling, medecine, ed. G. Jaouen, Wiley-VCH, Weinheim, 2006, pp. 215-262.

13. S. Clède and C. Policar, Chem. Eur. J., 2015, 21, 942-958.

14. S. Hostachy, C. Policar and N. Delsuc, Coord. Chem. Rev., 2017, 351, 172-188.

15. J. Schindelin, I. Arganda-Carreras, E. Frise, V. Kaynig, M. Longair, T. Pietzsch, S. Preibisch, C. Rueden, S. Saalfeld, B. Schmid, J.-Y. Tinevez, D. J. White, V. Hartenstein, K. Eliceiri, P. Tomancak and A. Cardona, Nature Methods, 2012, 9, 676-682.

16. C. A. Schneider, W. S. Rasband and K. W. Eliceiri, Nature methods, 2012, 9, 671-675.

17. A. Somogyi, K. Medjoubi, G. Baranton, V. Le Roux, M. Ribbens, F. Polack, P. Philippot and J. Samama, J Synchrotron Radiat, 2015, 22, 1118-1129.

18. K. Medjoubi, N. Leclercq, F. Langlois, A. Buteau, S. Lé, S. Poirier, P. Mercère, M. Sforna, C. Kewish and A. Somogyi, J Synchrotron Radiat, 2013, 20, 293-299.

19. J. W. Eaton, D. Bateman, S. Hauberg and R. Wehbring, \{GNU Octave\} version 4.0.0 manual: a high-level interactive language for numerical computations, 2015. 